\title{
The Art of a Reigning Queen as Dynastic Propaganda in Twelfth-Century Spain
}

\author{
By Therese Martin
}

Recent studies of queenship have allowed us to look closely at various aspects of the life of a ruler's consort, from patronage to reputation to commemoration, with a focus on the queens who were wives or mothers of kings. This study, however, will focus on Urraca of León-Castile (reigned 1109-26) to examine the unusual role of a reigning queen, that is, the king's daughter and heir to his throne, whose position carried a greater dynastic weight than did a queen consort's. ${ }^{1}$ The latter, although far from powerless, wielded authority only because she was married to a king or, in the case of regents and widows, was the mother of a king. ${ }^{2}$ These women married into the royal line, whereas reigning queens were of the royal line. In the central Middle Ages, reigning queens were a brief anomaly of the twelfth century, a not-altogether-successful experiment from the point of view of their courts and their heirs. Matilda of England (d. 1167), Melisende of Jerusalem (d. 1161), and Urraca of León-Castile (d. 1126) inherited their kingdoms from their fathers. ${ }^{3}$ All had turbulent reigns, brought on by parallel situations: the kings, lacking legitimate sons, named daughters as heirs to the throne, but pow-

I am grateful to James D'Emilio and Judith Golden for their comments on a prior version of this article, and to the anonymous Speculum readers, whose suggestions were most helpful. Much of this study was written with the support of a Getty Postdoctoral Fellowship in Spain in 2002-3. All translations are my own.

1 Theresa M. Vann, "The Theory and Practice of Medieval Castilian Queenship," in Queens, Regents and Potentates, ed. Theresa M. Vann, Women of Power 1 (Dallas, Tex., 1993), pp. 125-47, esp. p. 146, points out that according to the law in thirteenth-century Castile-León (both the Espéculo and the Siete partidas of Alfonso X), a queen derived honor from her husband the king and exercised power through him: "Her most important role was the preservation of the king's lineage." This is a key difference between a queen consort and a queen regnant: the latter worked to preserve her own lineage.

${ }^{2}$ Eleanor of Aquitaine (d. 1204), perhaps the best known of all medieval queens, demonstrates that a queen consort could indeed wield significant power. However, her role differed from that of a queen regnant, and thus her political strategies and patronage were also different. For Eleànor's role as patron, see George T. Beech, "The Eleanor of Aquitaine Vase, William IX of Aquitaine, and Muslim Spain," Gesta 32 (1993), 3-10; Madeline H. Caviness, "Anchoress, Abbess, and Queen: Donors and Patrons or Intercessors and Matrons?" in The Cultural Patronage of Medieval Women, ed. June Hall McCash (Athens, Ga., 1996), pp. 105-54; Nurith Kenaan-Kedar, "Aliénor d'Aquitaine conduite en captivité: Les peintures murales commémoratives de Sainte-Radegonde de Chinon," Cahiers de civilisation médiévale 41 (1998), 317-30; and the studies in Eleanor of Aquitaine: Lord and Lady, ed. Bonnie Wheeler and John Carmi Parsons (New York, 2003). See also the classic study edited by William W. Kibler, Eleanor of Aquitaine: Patron and Politician, Symposia in the Arts and the Humanities 3 (Austin, Tex., 1976).

${ }^{3}$ Although brief mention of the similar circumstances surrounding these three reigning queens has been made by several authors, including Bernard F. Reilly, Richard Fletcher, and Marjorie Chibnall, no study has yet undertaken a systematic comparison. 
erful opposition to the new queens arose after their fathers' deaths. Of the three, Urraca is the least well known today, but the one who ruled her kingdom the longest, seventeen years. She was the daughter of the powerful king Alfonso VI (reigned 1065-1109), who, despite his six wives, left no son to follow him as king. Today, if Queen Urraca is remembered at all, it is for the "turbulence" of her reign, the word of choice among those who have discussed her. Bernard Reilly rightly criticized "the prevailing tendency . . . to consider Urraca's reign as a kind of interregnum to be discussed and dismissed as quickly as possible." 4 Despite Reilly's efforts to counteract that tendency, it is still all too evident in the 1998 volume of the generally excellent Menéndez Pidal History of Spain series. The chapter dealing with Urraca's father is entitled "The Spain of Alfonso VI," and that covering her son's rule is "The Empire of Alfonso VII"; Urraca's seventeenyear reign disappears under the chapter heading "From Alfonso VI to Alfonso VII."s Her reign deserves to be reexamined. Urraca carried out a series of strategies that secured her place on the throne and solidified her unique position as queen regnant, including, as I argue, architectural patronage. Also among those strategies were the public acknowledgment of her favorite from the upper nobility and her command of the military, actions proper to a monarch, though surprising in a medieval queen. In short, Urraca lived as a king rather than a queen. However, her political triumphs during her lifetime brought a backlash after her death. From the thirteenth century on, chroniclers and historians excoriated Urraca and blamed her immorality for destroying peace in her day. Clearly, Urraca did not conform to the standards of behavior developed for queen consorts and applied retroactively to this twelfth-century reigning queen.

It is not mere coincidence that Urraca, Matilda, and Melisende were near contemporaries, for they reigned just before the idea of queenship that is still prevalent today solidified in the thirteenth century into the role of mediatrix, following the celestial example of Mary. ${ }^{6}$ The unusual nature of a queen regnant has caused Urraca to be forgotten as patron because she did not play the part of good wife and pure mother, the topos of the medieval queen. This study examines the reign

\footnotetext{
${ }^{4}$ The essential starting point for any study of Urraca is Bernard F. Reilly, The Kingdom of LeónCastilla under Queen Urraca, 1109-1126 (Princeton, N.J., 1982), also published by the Library of Iberian Resources Online (LIBRO) at http://libro.uca.edu/urraca/urraca.htm. See p. $x$ for the quotation.

${ }^{5}$ Miguel Ángel Ladero Quesada, La reconquista y el proceso de diferenciación política (1035-1217), Historia de España Menéndez Pidal 9 (Madrid, 1998).

${ }^{6}$ See the studies in Pauline Stafford, Queens, Concubines, and Dowagers: The King's Wife in the Early Middle Ages (Athens, Ga., 1983; repr. London, 1998); John Carmi Parsons, ed., Medicval Queenship (New York, 1993); and Anne J. Duggan, ed., Queens and Queenship in Medieval Europe (Woodbridge, Eng., 1997). Duggan's excellent introduction points out (pp. xx-xxi) that "while the position of a queen- or empress-consort was fairly well defined in custom and in law, that of the queen regnant presented conceptual and legal difficulties. Queenship had been constructed as a status complementary to that of the male ruler, not powerless ... but not in itself the source of power. A queen regnant was therefore anomalous and in the usual run of events exceptional." See also María Jesús Fuente Pérez, Reinas medievales en los reinos hispánicos (Madrid, 2003), the first synthetic attempt to look at Iberian queens across the Middle Ages. Although overly dependent on epics and later chronicles rather than contemporary documentation, it makes a significant contribution to the field. The Salic law preventing female inheritance of the throne in France was not applied before the fourteenth century. For a complete discussion, see Katherine Fischer Drew, The Laws of the Salian Franks (Philadelphia, 1991).
} 
of Queen Urraca and the ways she used patronage, especially at San Isidoro in León, in her successful bid to hold the throne. ${ }^{7}$ Following an in-depth look at Urraca, the reigns of Melisende and Matilda and their political uses of patronage are also addressed. These rare individuals provide the most appropriate comparative material, given the similarity of their circumstances to Urraca's. ${ }^{8}$

It is my contention that the construction of the royal monastic church of San Isidoro in León (Figs. 1 and 2), built c. 1095-1124, responded to the purposeful, ideological aims of Queen Urraca. Patronage formed part of an overall political agenda to maintain her unprecedented place on the throne as a reigning queen. San Isidoro was Urraca's family church in her capital city. A small chapel had been built c. 1055 on the site by her grandparents, and her aunt, the infanta Urraca, had begun to replace it with a Romanesque construction before her death in 1101. Structural and archaeological evidence shows that it would have been a transeptless basilica covered with a wooden roof, had the infanta lived to see it to completion. Instead, Queen Urraca undertook to continue building the church, but with a twist that emphasized her dynastic status and recalled important pilgrimage sites. The new design included a strongly projecting transept and barrel

\footnotetext{
${ }^{7}$ The extensive and growing bibliography on medieval female patronage includes Constance $\mathrm{H}$. Berman, "Women as Donors and Patrons to Southern French Monasteries in the Twelfth and Thirteenth Centuries," in The Worlds of Medieval Women: Creativity, Influence, Imagination, ed. Constance H. Berman, Charles W. Connell, and Judith Rice Rothschild, Literary and Historical Perspectives of the Middle Ages 2 (Morgantown, W.Va., 1985), pp. 53-68; Renate Bridenthal, Claudia Koonz, and Susan Stuard, eds., Becoming Visible: Women in European History, 2nd ed. (Boston, 1987); Mary Erler and Maryanne Kowaleski, eds., Women and Power in the Middle Ages (Athens, Ga., 1988); Gerald A. Bond, The Loving Subject: Desire, Eloquence, and Power in Romanesque France (Philadelphia, 1995); Paul Crossley, "The Architecture of Queenship: Royal Saints, Female Dynasties and the Spread of Gothic Architecture in Central Europe," in Queens and Queenship, ed. Duggan, pp. 263300; Georges Duby, Women of the Twelfth Century, trans. Jean Birrell, 3 vols. (Chicago, 1997-98); Dick Harrison, The Age of Abbesses and Queens: Gender and Political Culture in Early Medieval Europe (Lund, 1998); Catherine King, Renaissance Women Patrons: Wives and Widows in Italy, c. 1300-c. 1550 (Manchester, Eng., 1998); Jane Tibbetts Schulenburg, Forgetful of Their Sex: Female Sanctity and Society ca. 500-1100 (Chicago, 1998); Theodore Evergates, ed., Aristocratic Women in Medieval France (Philadelphia, 1999); Elisabeth van Houts, Memory and Gender in Medieval Europe, 900-1200 (Toronto, 1999); Fredric L. Cheyette, Ermengard of Narbonne and the World of the Troubadours (Ithaca, N.Y., 2001); and Kimberly LoPrete, Adela of Blois, Countess and Lord (forthcoming).

${ }^{8}$ Matilda of Tuscany (d. 1115), though a figure of power, was a countess rather than a queen. For an incisive evaluation of Matilda and her biographer, Donizo, see Patricia Skinner, "Gender and Memory in Medieval Italy," in Medieval Memories: Men, Women and the Past, 700-1300, ed. Elisabeth van Houts (Harlow, Eng., 2001), pp. 36-52. See also Aldo Cicinelli, ed., Matilde, Mantova e i palazzi del borgo: I ritrovati affreschi del Palazzo della ragione e del Palazzetto dell'abate (Mantua, 1995). While I recognize that the countess exercised authority over a large territory and took an active role in political events of her day, her rule was subordinate to that of the German emperor; a reigning queen, by contrast, could consider herself the emperor's equal. To admit Matilda's patronage here would mean opening the door to the many women of power in the twelfth century, such as Teresa of Portugal, Urraca's illegitimate half sister, who, after the death of her husband in 1112 and until her son managed to defeat her in 1128 , effectively ruled what would later become the kingdom of Portugal. Such women fully merit a study of their own, but they are beyond the scope of this article. While Petronila of Aragon (1136-73) fits the pattern of inheriting the throne from her father, the fact that she did so before the age of two, then was brought up in the court of her betrothed, Count Ramón Berenguer IV of Barcelona, while he ruled in her place, kept her from exercising the kind of power held by the three queens in this study.
} 
vaulting, along with some peculiar architectural details, discussed below. At the same time, the queen aligned her church with Toledo and Santiago de Compostela, the ecclesiastical powers of her day, and connected it to contemporary artistic trends beyond the borders of her kingdom. I credit Urraca with the major patronage of San Isidoro both because of the coincidence of dates-Urraca ruled from 1109 to 1126; the sculpture was completed in the first quarter of the twelfth century-and because its construction fits neatly with her political strategies, discussed below. In a previous article I undertook to explain how Urraca came to be all but written out of history. ${ }^{9}$ Here I examine the role patronage of architecture played as one of the tactics that allowed a woman to rule a kingdom in the Middle Ages.

Recovering the history of Queen Urraca's patronage of San Isidoro is important not only because it has gone unrecognized but also because it was one of the effective strategies that contributed to her successful rule. The architectural vocabulary in the early-twelfth-century church served to emphasize Urraca's status as legitimate heir to the throne, for the building acted as a permanent, public link between the queen and her illustrious father, Alfonso VI. Evidence that she was recognized as a patron of San Isidoro in the twelfth century is provided by the obituary of the Augustinian canons. After the canons took up residence at San Isidoro in 1148 , they began to keep an obituary that demonstrates whom among the royalty they considered as the major patrons of San Isidoro. ${ }^{10}$ Only two members of the royal family were originally recorded in the twelfth-century obituary: Fernando I (d. 1065) and Queen Urraca (d. 1126), while the infanta Sancha was added at her death in $1159 .{ }^{11}$ The names of many other members of the royal family were inserted a century later, when long, elaborate obits were devised. I interpret the inclusion in the twelfth-century obituary of just these three royal figures as the way by which the canons honored San Isidoro's most important patrons and remembered them on the anniversary of their deaths. Each had provided something essential to the continued future of the canonry at San Isidoro: Fernando I had brought the relics of the Visigothic bishop to León; Urraca had built the grand church; and the infanta Sancha brought the canons themselves to the site.

The significance of the Augustinian obituary for the history of San Isidoro has been disregarded since scholars expected to be able to associate the construction

\footnotetext{
${ }^{9}$ Therese Martin, "De 'gran prudencia, graciosa habla y elocuencia' a 'mujer de poco juicio y ruin opinion': Recuperando la historia perdida de la reina Urraca (1109-1126)," forthcoming in Compostellanum (2005).

${ }^{10}$ The obituary and other early manuscripts of San Isidoro have been studied by Ana I. Suárez González in Los códices III.1, III.2, III.3, IV y V (Biblia, Liber capituli, Misal), Patrimonio Cultural de San Isidoro de León B/2 (León, 1997). (I am grateful to the author for the assistance she has offered me on questions of paleography at San Isidoro.)

${ }^{11}$ Few scholars have noted the inclusion of Fernando I, Queen Urraca, and the infanta Sancha in the twelfth-century obituary, and those who have, failed to recognize the importance of the obituary for the history of the site. See Julio Pérez Llamazares, "La Catedral de León, III: Adiciones al Martirologio de los reglares," Anales del Instituto de León 12 (1919), 368; his Vida y milagros del glorioso San Isidoro, arzobispo de Sevilla y patrono del reino de León (León, 1924), p. 203; and Luisa García Calles, Doña Sancha, hermana del emperador (León, 1972), p. 55.
} 


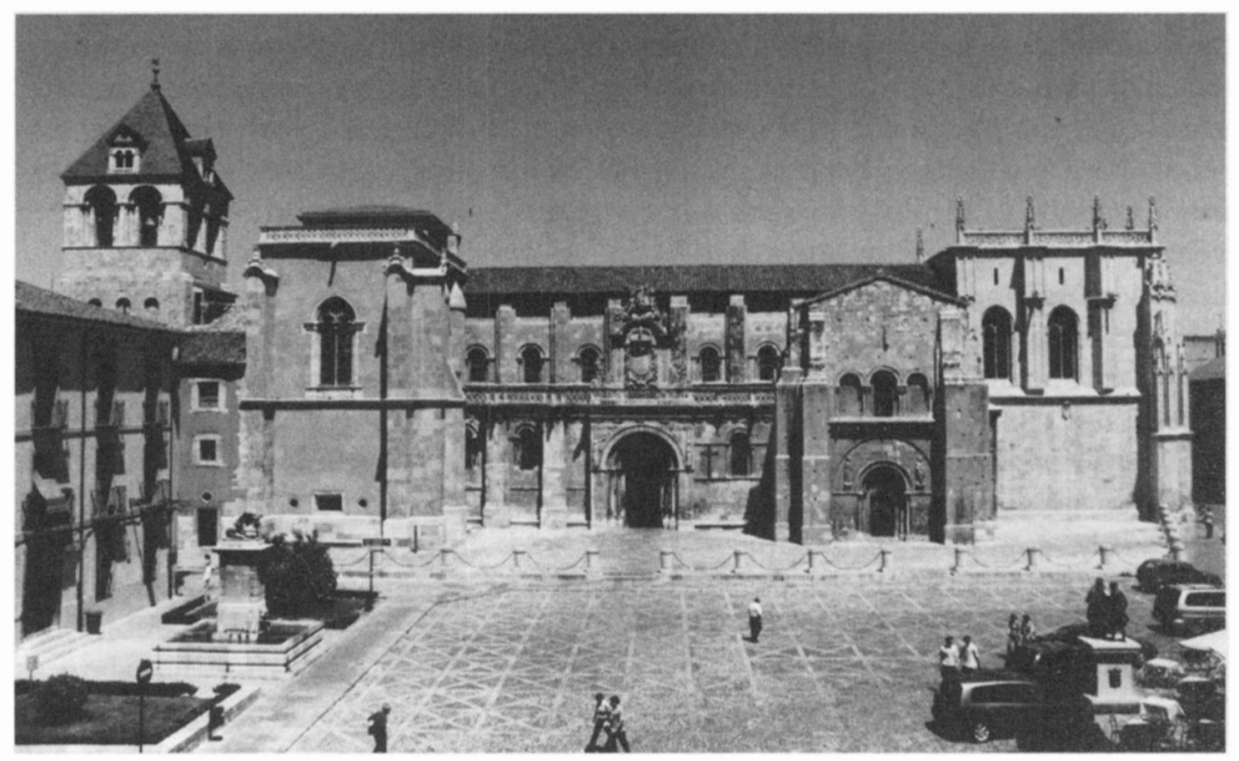

Fig. 1. San Isidoro de León, south facade, c. 1095-1124.

(Photograph: author.)

of the royal basilica with one king or another, but Alfonso VI (d. 1109) seemed too early and Alfonso VII (d. 1157) too late. They have also considered Urraca's aunt, the infanta Urraca (d. 1101), and her daughter, the infanta Sancha (d. 1159), as appropriate patrons for San Isidoro. Both royal princesses were renowned in their own days for their piety, virginity, and generosity to San Isidoro. To whom better, then, to attribute the role of patron of the grand new church than these holy women? However, a dispassionate review of the stylistic, iconographic, archaeological, and written evidence points to Queen Urraca as patron..$^{12}$ What is more, the queen was the only member of the royal family who had an urgent need to produce such a major public work. Urraca, all but forgotten today, was a powerful monarch whose successful reign was cut short by her death in childbirth at age forty-five. She was a ruler but not a king, nor did she fit the image of the proper medieval queen, who acted as a go-between for her lord and his people. In a family famous for pious virgins, Urraca came to be known for warring with her second husband and taking a lover, with whom she had two children. In the eyes of later scholars, this evidently disqualified her from consideration as a possible patron of San Isidoro.

The traditional studies identifying virgin princesses as patrons began with Manuel Gómez-Moreno's magisterial works of 1925-26 and 1934, researched in

\footnotetext{
${ }^{12}$ I discuss the evidence at length in my forthcoming book, Queen as King: Politics and Architectural Propaganda in Twelfth-Century Spain (Leiden, 2006).
} 


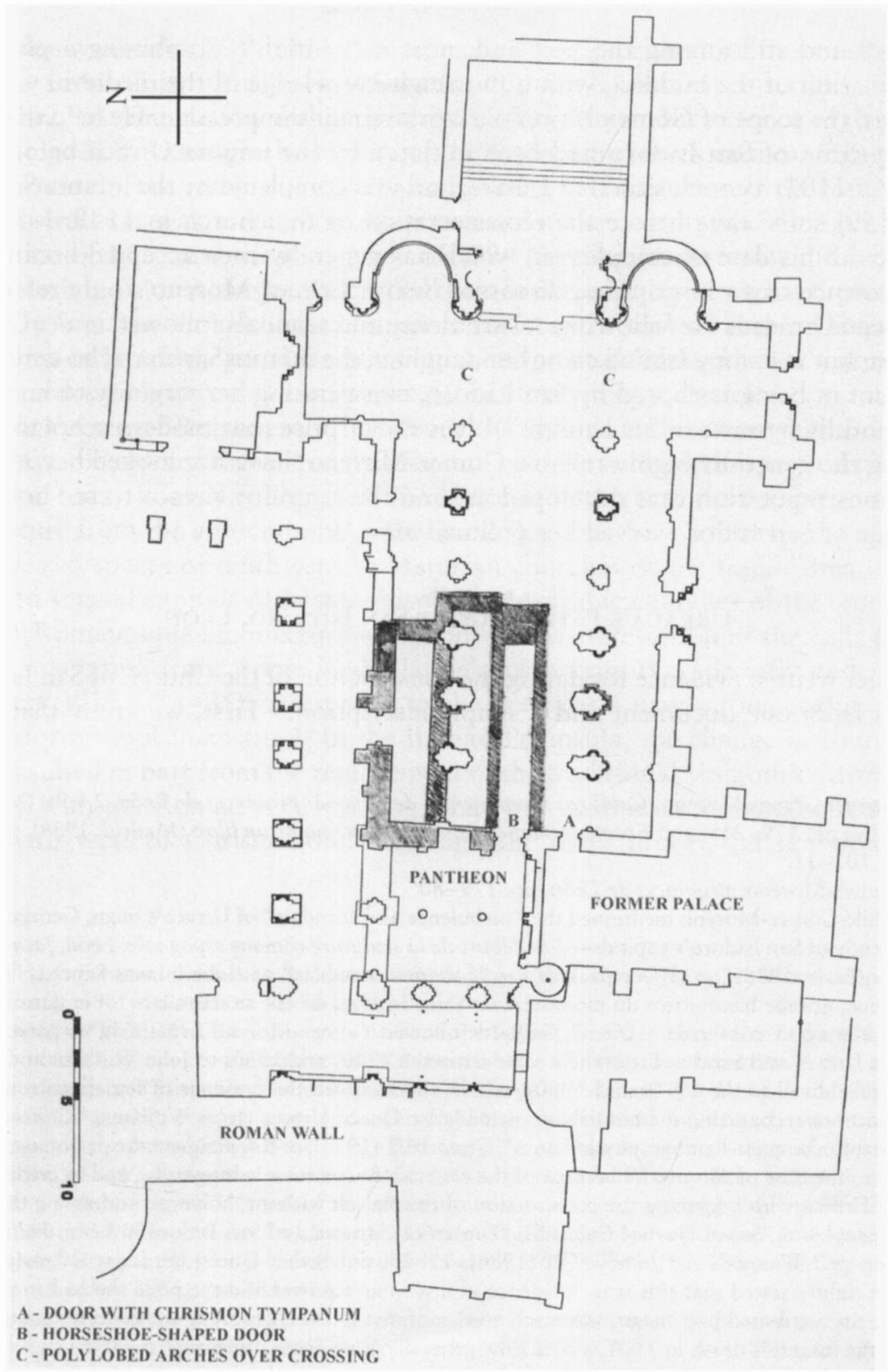

Fig. 2. Ground plan, San Isidoro de León.

Shaded area c. 1055 .

(Drawing by Pedro Neira Olmedo; (C) Therese Martin.) 
1906-8 and still among the best and most influential. ${ }^{13}$ Combining a physical examination of the building with a thorough knowledge of the medieval written sources, the scope of Gómez-Moreno's work remains impressive. He held that the construction of San Isidoro had been initiated by the infanta Urraca before her death in 1101, a conclusion that I share, and was completed by the infanta Sancha (d. 1159) some time before the reconsecration of the church in 1149. I do not agree with his date of completion, which has generally been accepted because of the presence of an inscription, discussed below. Gómez-Moreno's only reference to Queen Urraca is the following: "Turbulence and scandals followed under Queen Urraca; but in compensation came her daughter, the infanta Sancha, who emulated her aunt in being harbored by San Isidoro, consecrating her virginity to him as a wife and living next to his church." 14 It is no surprise that modern scholars, following the generally highly reliable Gómez-Moreno, have not looked beyond the infamous reputation that developed around the figure of Urraca to see how patronage of San Isidoro served her political aims. ${ }^{15}$

\section{Urraca's Patronage at San Isidoro, León}

Direct written evidence for dating the construction of the Church of San Isidoro comes from one document and a simple inscription. ${ }^{16}$ First, we know that con-

${ }^{13}$ Manuel Gómez-Moreno, Catálogo monumental de España: Provincia de León, 2 vols. (Madrid, 1925-26), pp. 179-215; and El arte románico español, esquema de un libro (Madrid, 1934), pp. 5865 and $102-11$.

${ }^{14}$ Gómez-Moreno, Provincia de León, pp. 179-80.

${ }^{15}$ While Gómez-Moreno mentioned the "turbulence and scandals" of Urraca's reign, Georges Gaillard's study of San Isidoro's capitals - Les débuts de la sculpture romane espagnole: León, Jaca, Compostelle (Paris, 1938), p. 13-contrasted her "continual troubles" with the infanta Sancha, "fille de cette reine, grande bienfaitrice du monastère de Saint-Isidore, où elle se retira très tôt et dans la paix duquel elle vécut consacrée à Dieu." Gaillard followed Gómez-Moreno in naming as patrons the infantas Urraca and Sancha. From these scholars in the 1920s and 1930s to John Williams and Susan Havens Caldwell in the 1970s and 1980s, scholars have noted the presence of female patronage in León without recognizing the contributions made by Queen Urraca. John Williams, "Generationes Abrahae: Reconquest Iconography in León," Gesta 16/2 (1977), 3-14, assigned the patronage of San Isidoro to the time of Alfonso VI because of the church's Reconquest iconography, and he credited the infanta Urraca with beginning the construction of the church without, however, addressing the issue of its completion. Susan Havens Caldwell, "Urraca of Zamora and San Isidoro in León: Fulfillment of a Legacy," Woman's Art Journal 7/1 (1986), 19-25, noted that Queen Urraca was "maligned," and she rightly stated that this was "evidence of a woman's power and the price she had to pay for it," but she attributed patronage exclusively to the infanta Urraca, assuming the church's completion before the infanta's death in 1101, a date now generally considered too early.

${ }^{16}$ Other documents survive for the later phases of construction of the monastic complex. An unfinished draft of the infanta Sancha's will c. 1140-44 and a donation by Fernando II in 1171 specified funds for construction. Sancha's will was left incomplete, but we can see from her donations of 114858 that she later carried out her intention of funding San Isidoro, where construction of the late Romanesque cloister and the completion of the bell tower took place c. 1150. See María Encarnación Martín López, "Colección documental de la infanta doña Sancha (1118-1159): Estudio crítico," in León y su bistoria: Miscelánea bistórica, 8, Colección Fuentes y Estudios de Historia Leonesa 99 (León, 2003), pp. 290-91. For Fernando II's donation, see María Encarnación Martín López, Documentos de los siglos X-XIII: Colección diplomática, Patrimonio Cultural de San Isidoro de León A/1/1 (León, 1995), pp. 126-27. 
struction was under way in 1110 because of a donation given "for the construction of San Isidoro" by a member of Urraca's court. ${ }^{17}$ Second, an inscription of the year 1124 in conjunction with a mason's mark is now on the exterior of the north apse (Fig. 3)..$^{18}$ Although the brevity of the inscription leaves its meaning open to interpretation, the carving of a date on a building to commemorate the completion of construction was a common phenomenon in the central Middle Ages. ${ }^{19}$ The donation of 1110 and the inscription of 1124 have long been known to scholars, but little importance has been accorded them because Urraca's reign was presumed to have been too tumultuous to support the construction of such an important building. In fact, they provide a starting point for establishing Urraca's patronage of the redesign and completion of the grand Romanesque church.

I use the term "Romanesque" to define the style of architecture that arrived in León-Castile toward the end of the eleventh century with precedents in regions of the land today known as France. Churches built in this new design were a radical departure from the autochthonous Iberian styles, whether the cramped, compartmentalized spaces of ninth-century Asturian churches or the fragile arcades and stylized vegetal capitals of Islamic-inspired Mozarabic churches of the tenth century. ${ }^{20}$ Romanesque architecture was a physical manifestation of the calls for reform emanating from Rome in the late eleventh century, especially under Pope Gregory VII (1073-85), a response to the need for a new setting within which to perform the Roman rite. ${ }^{21}$ In the Iberian Peninsula, the change in church design resulted in part from the replacement of the traditional Visigothic-Mozarabic liturgy with the Roman rite, bringing what was at times a marginal territory in line with western Christendom. Although the older liturgy did not disappear

17 Luciano Serrano, Cartulario del monasterio de Vega (Madrid, 1927), p. 37; Martín López, Documentos, p. 39: "in illo labore Sancti Isidori."

${ }^{18}$ Literally, "E(ra) MCLXII." The year 1162 in the Spanish era is the equivalent of A.D. 1124. In the twelfth century, Spain continued to use a Roman system of dating that began in 38 B.C., the year Augustus conquered Hispania. The combination of volute-shaped mark and date provides suggestive evidence for the construction history of the church. This mark is found mainly at the west end of the church and in the second story of the palace to the southwest, thus in the final stages of construction. The mason's mark clarifies the meaning of the date as a commemoration of the completion of San Isidoro, as did the original location of this stone on the west end of the church. See my "Reading the Walls: Masons' Marks and the Archaeology of Architecture at San Isidoro, León," in Church, State, Vellum, and Stone: Essays on Medieval Spain in Honor of John Williams, ed. Therese Martin and Julie A. Harris (Leiden, 2005), pp. 383-422.

${ }^{19}$ Two inscriptions as brief as San Isidoro's that have been interpreted as dates of completion can be found in northern Spain at Celada de Roblecedo ("ERA MCCXII" [A.D. 1174]) and Aguilar de Campoo ("ERA MCCLVII" [A.D. 1219]). Many exterior inscriptions were more explicit, such as the one at San Pedro de Duratón located at the base of a buttress near the south portal. It names the patron, consecrating bishop, master builder, and the year in which it was dedicated (A.D. 1100). For the full inscription of Duratón, among others, see Pedro Luis Huerta Huerta, "Hablan las fuentes: Aproximación documental al edificio románico," in Perfiles del arte románico (Aguilar de Campoo, 2002), pp. 27-51.

${ }^{20}$ For pre-Romanesque architecture in Spain, see Achim Arbeiter and Sabine Noack-Haley, Christliche Denkmäler des frühen Mittelalters vom 8. bis ins 11. Jahrhundert (Mainz am Rhein, 1999).

${ }^{21}$ For an overview of the period, see Giles Constable, The Reformation of the Twelfth Century (Cambridge, Eng., 1996); and H. E. J. Cowdrey, Pope Gregory VII, 1073-1085 (Oxford, 1998). 


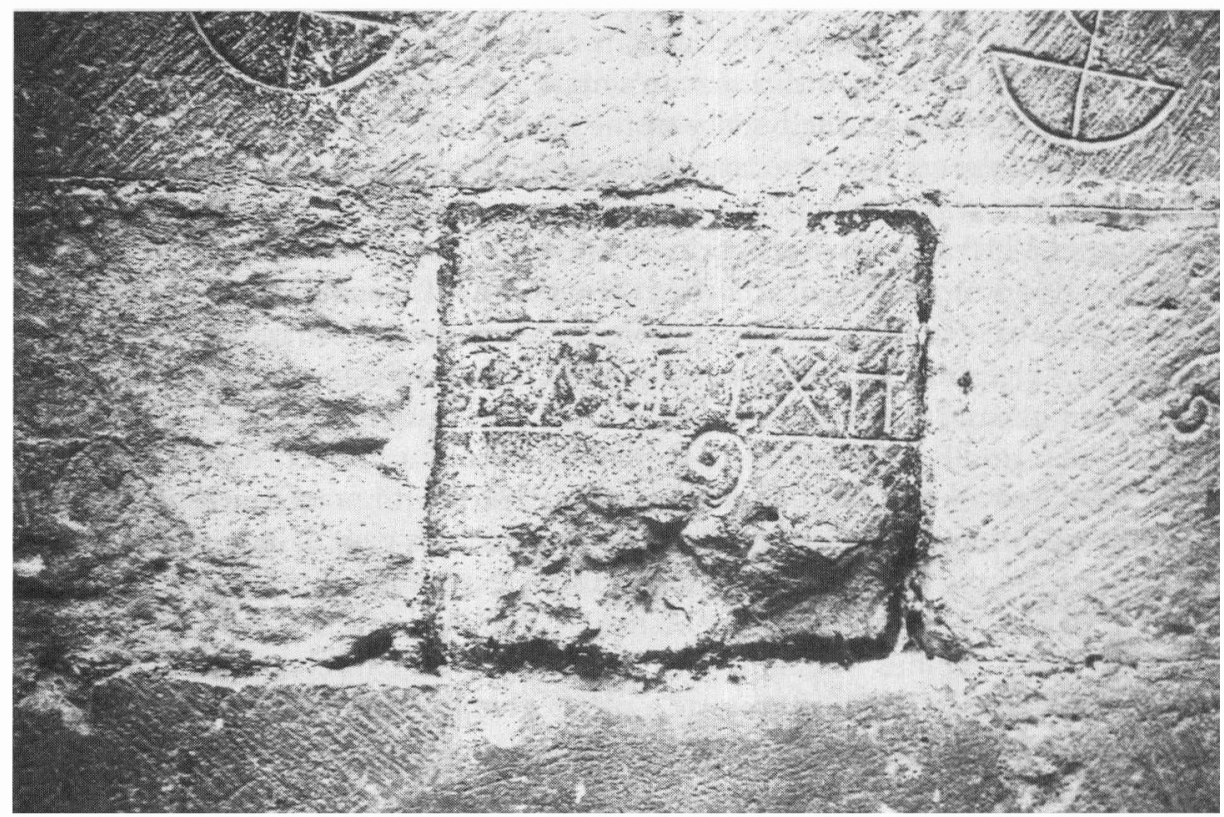

Fig. 3. 1124 inscription, exterior of north apse, San Isidoro de León. (Photograph: author.)

immediately, this standardized rite came to replace it, beginning in León under Alfonso VI. ${ }^{22}$

The radical change in ecclesiastical architecture to what is now called Romanesque can be seen clearly in a comparison of the ground plans (see Fig. 2) of the church completed in 1124 under the patronage of Urraca with that built c. 1055 by her grandparents, Sancha (d. 1067) and Fernando I (d. 1065).23 The squared apse and compressed dimensions of the earlier church bespeak a building designed for use by religious and for attendance by the royal family alone. Urraca's church, nearly five times as large, with a prominently projecting transept and two sets of doors open to the public, responded to the increasing demand for involvement of the laity. Besides the physical space of vaulted nave and side aisles divided by compound piers supporting an arcade, the new church of San Isidoro declares itself part of the international Romanesque style by its proliferation of historiated capitals and elaborate portal sculpture. Specialists are generally in accord regard-

${ }^{22}$ See R. Gonzálvez, "The Persistence of the Mozarabic Liturgy in Toledo after A.D. 1080," in Santiago, Saint-Denis, and Saint Peter: The Reception of the Roman Liturgy in León-Castile in 1080, ed. Bernard F. Reilly (New York, 1985), pp. 167-85.

${ }^{23}$ Most of the north wall and part of the west wall of the $c .1055$ church survive. The ground plan was revealed by excavations. See Juan Eloy Díaz-Jiménez, "San Isidoro de León," Boletín de la Sociedad española de excursiones 25 (1917), 81-98; and John Williams, "San Isidoro in León: Evidence for a New History," Art Bulletin 55 (1973), 171-84. 
ing the dating of the nearly two hundred carved capitals at San Isidoro, situating the completion of the sculpture in the first quarter of the twelfth century, solidly within Urraca's reign. ${ }^{24}$ Stylistic analysis connects León to major constructions at Toulouse, Jaca, Frómista, Carrión de los Condes, and Santiago de Compostela, locating San Isidoro within a specific historical and artistic context at the turn of the twelfth century. ${ }^{25}$ Further, brief archaeological excavations in 1908 and 1970, when the flooring was replaced, allow us to see how the church would have been built if the infanta had seen it to completion. ${ }^{26}$ While much larger than her parents' chapel, the infanta's new building was to be a simple church without transepts or vaulting. The various sculptural workshops, along with foundations revealed in the excavations, allow us to recognize two distinct phases of construction within the church, which I identify with the patronage first of the infanta Urraca and then of her niece, Queen Urraca.

In addition to her turbulent personal and political history, the queen has not been recognized as patron because of inscriptions from the mid-twelfth and early thirteenth centuries. ${ }^{27}$ San Isidoro was reconsecrated in 1149 by her children, Alfonso VII and the infanta Sancha, and this has been accepted as the moment when construction was completed, even though the fabric of the building argues against such a late date. Just after the royal siblings installed Augustinian canons at San Isidoro in 1148, the dedication came during a period of renewed construction on the monastic complex at San Isidoro but long after the completion of the church itself. The consecration, held in the presence of many important lay and religious figures, was probably due to a combination of factors-Alfonso VII's success at the battle of Baeza in 1147, the installation of Augustinians in 1148, and perhaps a council in León in 1149-none of which involved the construction of the church.

Tomb inscriptions have also been used to assign the patronage of San Isidoro to members of the royal family other than Queen Urraca. According to the no-

\footnotetext{
${ }^{24}$ Marcel Durliat, in La sculpture romane de la route de Saint-Jacques: De Conques à Compostelle (Mont-de-Marsan, 1990), p. 389, correctly stated that "stylistiquement, aucune des sculptures de SaintIsidore ne paraît postérieure à 1125," yet he did not attribute any of the patronage of San Isidoro to Queen Urraca.

${ }^{25}$ For a more detailed analysis of the various sculptural styles at San Isidoro and their connections to other sites, as well as further bibliography on the topic, see my "Un nuevo contexto para el tímpano de la Portada del Cordero en San Isidoro de León," in El tímpano románico: Imágenes, estructura y audiencias, ed. Rocío Sánchez Ameijeiras and José Luis Senra Gabriel y Galán (Santiago de Compostela, 2003), pp. 181-205.

${ }^{26}$ See n. 23, above.

${ }^{27}$ See the recent studies by Ana Suárez González, “¿Del pergamino a la piedra? ¿De la piedra al pergamino? (entre diplomas, obituarios y epitafios medievales de San Isidoro de León)," Anuario de estudios medievales 33 (2003), 365-415; and Rocío Sánchez Ameijeiras, "The Eventful Life of the Royal Tombs of San Isidoro in León," in Church, State, Vellum, and Stone, ed. Martin and Harris, pp. 489-530. The inscriptions are published by Walter Muir Whitehill, Spanish Romanesque Architecture of the Eleventh Century (Oxford, 1941), pp. 151-53. They were first recorded in 1572 by Ambrosio de Morales, Viage por orden del Rey D. Phelipe II. á los Reynos de Leon y Galicia y Principado de Asturias, para reconocer las reliquias de santos, sepulcros reales, y libros manuscritos de los cathedrales y monasterios, ed. Enrique Flórez (Madrid, 1765; repr. 1791). I have consulted the Oviedo, 1977 facsimile of the 1791 edition.
} 
longer-extant tomb of the infanta Urraca, she "enlarged" the church built by her parents. ${ }^{28}$ How to interpret such a statement is less than obvious, first because the tomb was made during a general renovation of royal burials that took place around the turn of the thirteenth century, thus well after the church was built and a century after the infanta's death in $1101 .^{29}$ The inscription refers to the infanta as queen of Zamora, a title retroactively accorded her in the thirteenth century but never in use during her lifetime. Second, the exact meaning of the term "ampliavit" and, thus, the full extent of the enlargement are unclear from this brief text. My research indicates that the enlargement refers to the construction c. 1080 of the two-story royal apartments to the west of the church, the lower level of which is now known as the Pantheon. However, the infanta cannot have been responsible for the reconception of the church as a transepted, pilgrimage-type basilica, given her death in 1101 and the subsequent changes in plan and sculptural styles.

Another tomb, that of a certain Petrus, called Deustamben, has contributed to the confused dating and undefined patronage of San Isidoro. The inscription on Petrus's tomb credits him with "overbuilding" or "building up" the church, but again the term "superedificavit" is difficult to translate into modern architectural terms. ${ }^{30}$ It has been taken to mean that Petrus was responsible for vaulting the Church of San Isidoro, a reasonable interpretation. The inscription makes him a bridge builder, and the techniques for vaulting a building and constructing a bridge were not far removed. No dates are included in the inscription, but we know from the Pilgrim's Guide to Santiago de Compostela that he had died before it was written c. $1135 .{ }^{31}$ Because he was given burial by Alfonso VII and the infanta Sancha, scholars have assumed that Petrus worked for the king as "architect" of San Isidoro. We know, however, that Urraca had been Petrus's patron from the wording in an 1126 charter in which Alfonso VII confirmed a donation his recently

${ }^{28}$ Whitehill, Spanish Romanesque Architecture, p. 151. The tomb was destroyed in 1810 , when Napoleon's troops sacked the Pantheon (the palace area to the west of the church; see Fig. 2), but the text had been copied by Morales. See Suárez González, “¿Del pergamino a la piedra?” See also Santo Martino de León: Ponencias del I Congreso internacional sobre Santo Martino en el VIII centenario de su obra literaria, 1185-1985, Isidoriana 1 (León, 1987), esp. Vicente García Lobo, "Las inscripciones medievales de San Isidoro de León,” pp. 371-98, and José Ignacio Gil Pulido, “Los epitáfios del Panteón de los reyes de San Isidoro de León (999-1159): Problemas históricos," pp. 401-11.

${ }^{29}$ See Suárez González, “¿Del pergamino a la piedra?” esp. pp. 401-2; and Sánchez Ameijeiras, "The Eventful Life of the Royal Tombs."

${ }^{30}$ Whitehill, Spanish Romanesque Architecture, p. 153. Vicente García Lobo and Encarnación Martín López, De epigrafía medieval: Introducción y álbum (León, 1995), pp. 55 and 125, have dated the tomb inscription to the "renovatio" of the early thirteenth century at San Isidoro.

${ }^{31}$ Because of the reference to a bridge on Petrus's tomb, Gómez-Moreno, El arte románico español, p. 106, identified him as Petrus the bridge builder in the Pilgrim's Guide: "Petrus, qui Pontem Minee á regina Hurraca confractum refecit." See Paula Gerson, Annie Shaver-Crandell, Alison Stones, and Jeanne Krochalis, The Pilgrim's Guide to Santiago de Compostela: A Critical Edition, 2 (London, 1998), pp. 16 and 155-56. For a discussion of itinerant artists, including Petrus, see Serafín Moralejo, "Artistas, patronos y público en el arte del Camino de Santiago," Compostellanum 30 (1985), 399430, esp. pp. 398-99. Moralejo's complete works have recently been reedited in Patrimonio artístico de Galicia y otros estudios: Homenaje al Prof. Dr. Serafín Moralejo Álvarez, ed. Ángela Franco Mata, 3 vols. (Santiago de Compostela, 2004). 
deceased mother made to Petrus Peregrinus, the bridge builder. ${ }^{32}$ I would suggest that Petrus was the master of works called in by Queen Urraca when she decided to change the design of the church begun by her aunt from wooden-roofed to barrel-vaulted.

Without an unambiguous document in which a patron lays claim to San Isidoro, we must depend on visual evidence provided by the building and its sculpture and on the historical context to understand why the church was built. San Isidoro's sculpture clearly points to a construction date in the first quarter of the twelfth century; and when we examine Queen Urraca's political circumstances, the reasons for the construction of San Isidoro become clear. Architectural features visually connected Urraca to her father as his declared heir and to Toledo and Santiago, the most powerful religious centers in medieval Spain. San Isidoro served as a visible locus of the queen's power in her capital city and an affirmation of her legitimacy as ruler; it was built by Urraca precisely because her turbulent times required its impressive urban presence.

\section{The Queen as Legitimate Heir}

Despite the difficulties inherent in her unprecedented role as female monarch, Queen Urraca used a combination of patronage, political maneuvering, and especially the evocation of her father's memory to retain her place on the throne until her early death in 1126 . Urraca's efforts to associate herself with her father are manifested most clearly in the titles she used in her charters. Although it was common practice for a new ruler to emphasize his lineage upon ascending the throne, most references to a king's parentage disappeared within a few years, once the young king had established himself as monarch. During the seventeen years of her reign, Urraca as daughter (rather than son) of the king never seems to have been secure enough to give up invoking her father's name. In the early years of her reign, Urraca often emphasized her legitimacy by naming both parents, signing herself in 1112, "Urraca, queen of all Spain, daughter of the lord king Alfonso and queen Constanza." "33 More common were explicit references to her famous father, such as in 1110, "Urraca, by the grace of God queen and empress of Spain, daughter of the king and emperor Alfonso of blessed memory." ${ }^{34}$ Even to the end of her reign, Urraca's chancery continued to style her "Queen Urraca, daughter of the most pious Alfonso, emperor of all Spain." ${ }^{35}$ Her position as reigning queen

\footnotetext{
${ }^{32}$ For the full text of the 1126 charter, see Luis Vázquez de Parga, José María Lacarra, and José Uría Ríu, Las peregrinaciones a Santiago de Compostela, 3 (Madrid, 1948-49; repr. in facsimile, Asturias, 1981), pp. 15-16.

${ }^{33}$ Irene Ruiz Albi, La reina doña Urraca (1109-1126), cancillería y colección diplonática (León, 2003), pp. 418-20: "Urraca totius Yspanie regina, filia regis domni Adefonsi et Constantie regine." See also Cristina Monterde Albiac, ed., Diplomatario de la reina Urraca de Castilla y León (11091126) (Zaragoza, 1996), pp. 91-92.

${ }^{34}$ Ruiz Albi, La reina doña Urraca, pp. 371-73: "Vrracha, Dei gratia regina et imperatrix Yspanie, filia regis Ildefonsi beate memorie imperatoris." See also Monterde Albiac, Diplomatario de la reina Urraca, p. 37.

${ }^{35}$ Monterde Albiac, Diplomatario de la reina Urraca, p. 303, charter of September 1125: "Urracha regina, piissimi Aldefonsi tocius Yspanie imperatoris filia."
} 
was directly due to Alfonso VI's having declared in Toledo before court and followers that she was to rule after his death. Throughout her life, Queen Urraca ensured that this essential fact was not forgotten.

Visual evidence of Urraca's successful efforts to associate herself with her father is provided by the cartulary known as the Tumbo A of the Cathedral of Santiago de Compostela..$^{36}$ This collection of charters documenting royal gifts to the cathedral was put together in 1129-34, shortly after Urraca's death in 1126. The charters of the Tumbo A are punctuated by twenty-four images of the cathedral's royal patrons, fifteen of whom are crowned and enthroned monarchs holding scepters. ${ }^{37}$ These attributes of crown and scepter indicate the status as ruler of fourteen kings and Queen Urraca. ${ }^{38}$ In the other portraits of queen consorts, counts, and infantas, none of the royal figures bears the attributes of ruling power (Figs. 4 and 5). Some of the royalty are identified by tituli in the background or on the scrolls they hold, others merely by association with the donation on the same folio. ${ }^{39}$ Alfonso VI, however, is identified by a titulus that underlines his importance, lauding him above all others as "ADEFONS REX PATER PATRIE" (Fig. 6). Of the sixteen figures holding scrolls representing the charters they have bestowed upon the cathedral, only Urraca's scroll explicitly associates her with her father (Fig. 7) ${ }^{40}$ It reads, "URAKA REGINA ADEFONSI FILIA CONFIRMAT." In Alfonso's and Urraca's portraits, the manuscript painter used the tituli to emphasize the power of the king and the status Urraca attained through him. Alfonso's name on Urraca's image served to reinforce her legitimacy and that of her donation.

As scholars have noted to the exclusion of almost everything else when mentioning Urraca's reign, the first quarter of the twelfth century was a turbulent period in northern Iberia. The queen's accession to the throne was as unexpected in her day as it remains surprising in ours. She was the eldest child of Alfonso VI (d. 1109) and his second wife Constanza of Burgundy (d. 1093), but given the

${ }^{36}$ The portraits and charters of the Tumbo $A$ are reproduced in Manuel Lucas Álvarez, Tumbo A de la Catedral de Santiago: Estudio y edición, Colección Histórico-Documental de la Iglesia Compostelana 1 (Santiago de Compostela, 1998). For studies of the Tumbo A, see Manuel Rubén García Álvarez, "La primera parte del 'Tumbo A' de Santiago," Compostellanum 7 (1962), 531-67; and M. C. Díaz y Díaz, F. López Alsina, and S. Moralejo, eds., Los tumbos de Compostela (Madrid, 1985).

${ }^{37}$ For a recent study of the royal portraits, although not of Urraca's, see Manuel Antonio Castiñeiras González, "Poder, memoria y olvido: La galería de retratos regios en el Tumbo A de la Catedral de Santiago (1129-1134)," Quintana 1 (2002), 187-96.

${ }^{38}$ For the attributes of power, see C. Delgado Valero, "La corona como insignia de poder durante la edad media," Anales de historia del arte 4 (1993-94), 747-63; and "El cetro como insignia del poder durante la edad media," in Los clasicismos en el arte español: Actas del X congreso del C.E.H.A., [1] (Madrid, 1994), pp. 45-52.

${ }^{39}$ For the use of a scroll to identify the donor, see Michael Camille, "Seeing and Reading: Some Visual Implications of Medieval Literacy and Illiteracy," Art History 8 (1985), 26-49.

${ }^{40}$ Only four other scrolls identify the ruler, each less explicitly than Urraca's. They read as follows: "RANEMIRus REX CF"; "FREDENANDus REX CF"; "PETRus REX"; and "ENRICus COMES CF." Of the twelve portraits with a titulus in the background, just two connect the king to his father ("ORDONIus REX FILIus SECVNDus ADEFONSI" and "VEREMVDus REX ADEFONSI FILIVS"). Ordoño II (d. 924) and Vermudo III (d. 1037) were probably given patronymics because each was one of several kings by the same name. These two were less important historically than their eponymous relatives. Urraca, however, was the only queen to rule; there would have been no a priori need to make explicit her relationship to Alfonso VI. 


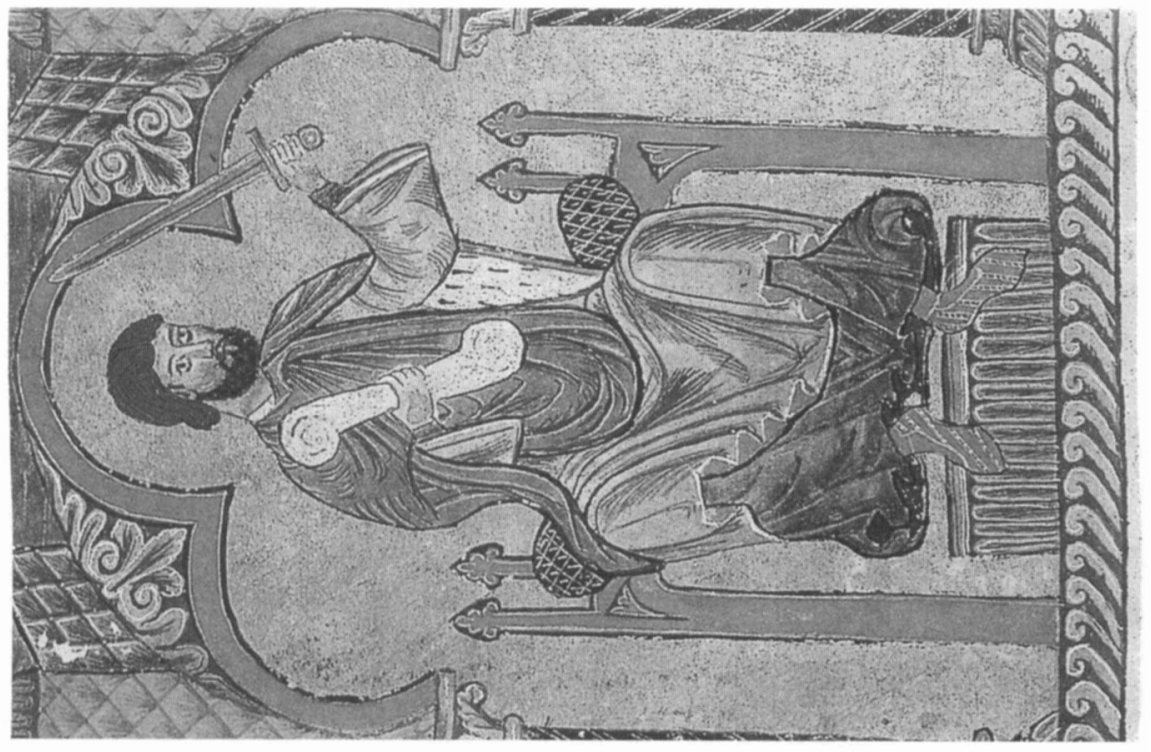

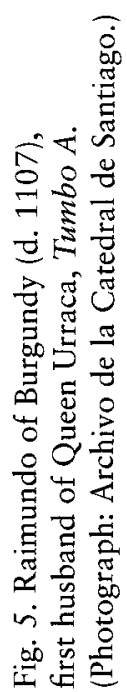
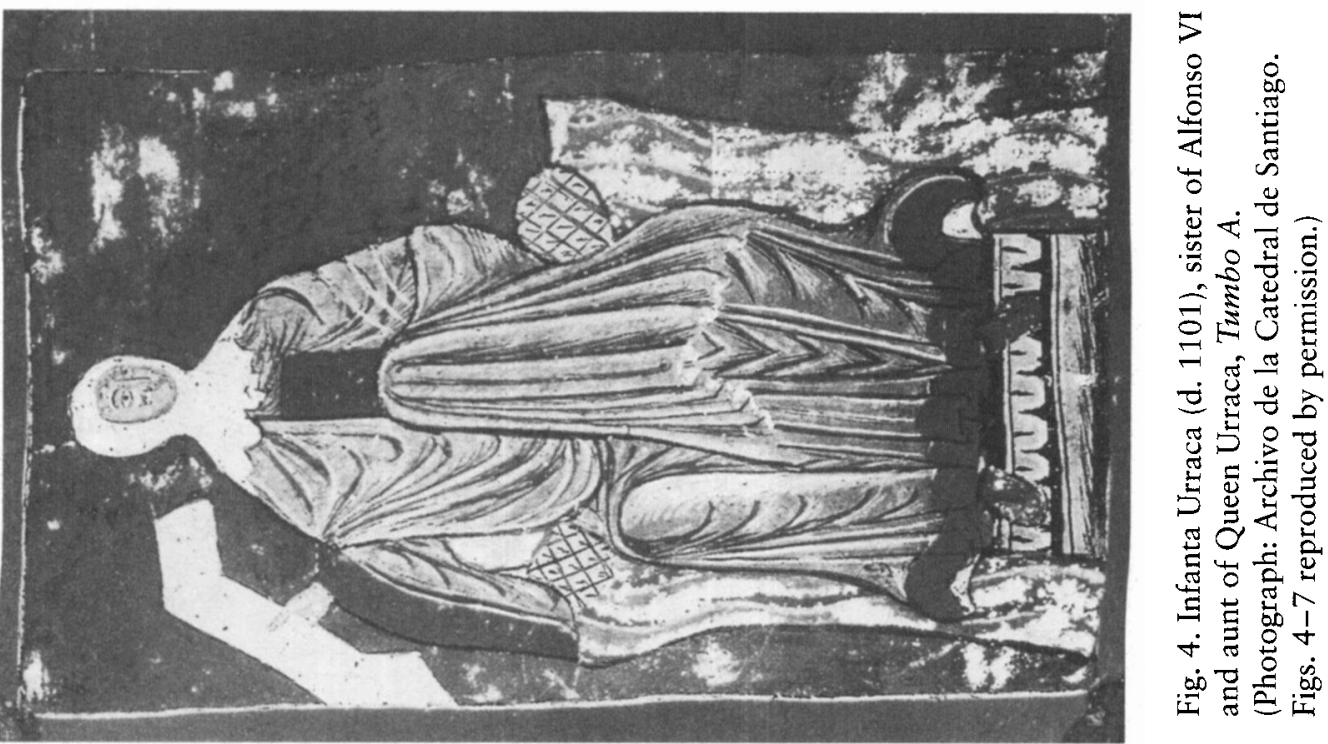

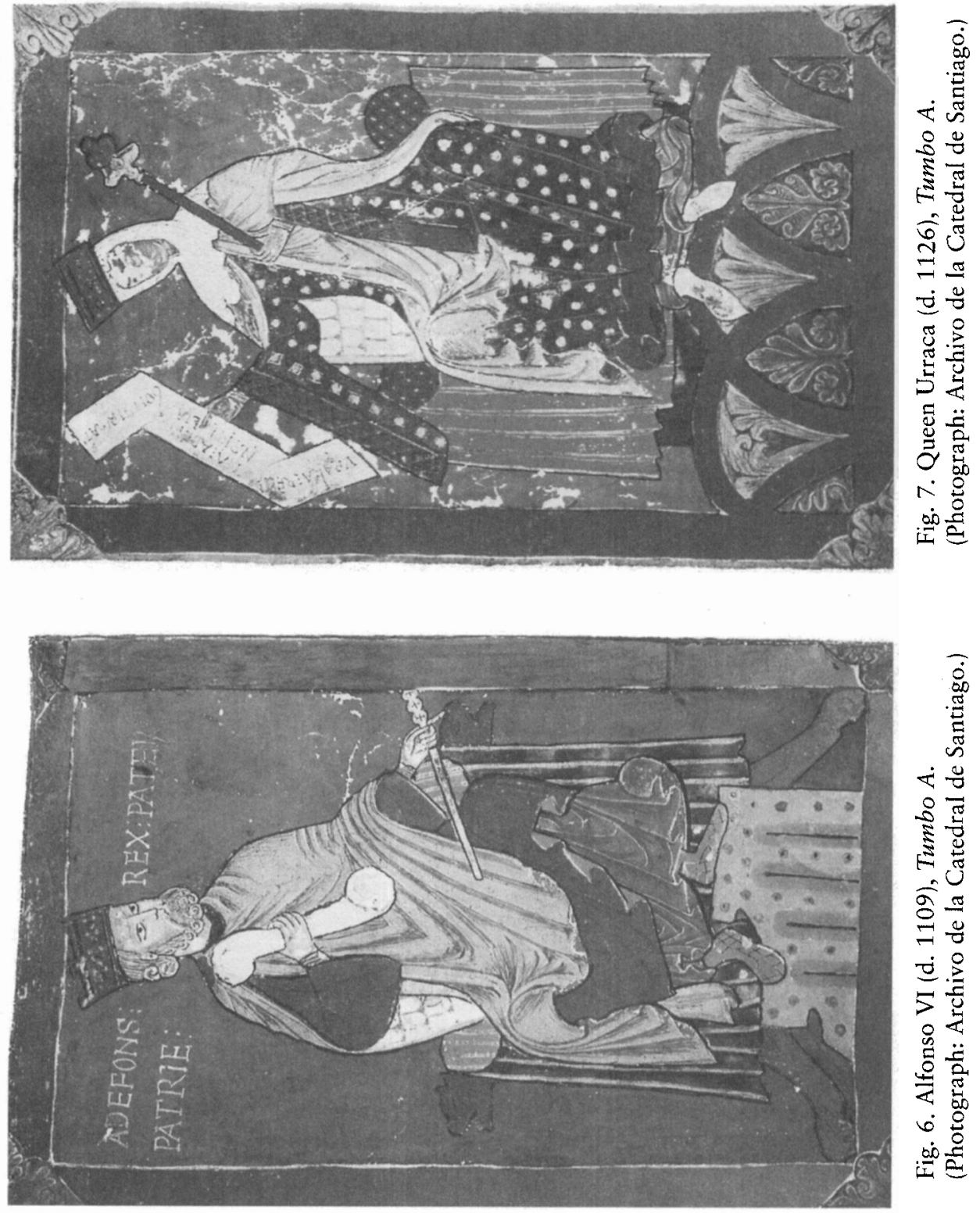
fact that Alfonso would marry six times and take a formal concubine, he must have expected to be succeeded by a son. Yet he had only six children to survive infancy, just one of them a boy, who died in battle at age fifteen. ${ }^{41}$ Seeing his death approach without a son to succeed him, Alfonso VI designated his eldest daughter as heir. Eight troubled years followed Urraca's accession, as the queen fought to maintain her right to rule against her estranged second husband on one front and against the supporters of her young son by her first husband on another. The complicated early years of her rule make it unsurprising that scholars have avoided designating Urraca as patron of San Isidoro, yet the evidence points to just this unrest as the catalyst for the church's construction. The new basilica served as homage to Urraca's father, a visible reminder of her position as legitimate successor to the throne of León..$^{42}$ Urraca's patronage of San Isidoro was a public and enduring manifestation to her subjects that she was her father's heir.

\section{The Significance of Toledo and Its Evocations in SAN Isidoro}

Two unusual architectural elements added to San Isidoro under Urraca's patronage, polylobed arches and a horseshoe-shaped door, were intended to signal her dynastic authority through her father by calling to mind Toledo. Although this interpretation must remain speculative, it is clear that some extraordinary justification is required to explain the exceptional presence of these architectural details in León. One of the most significant acts of Alfonso VI had been the reconquest in $\mathbf{1 0 8 5}$ of Toledo, a city important strategically and symbolically as the ancient Visigothic capital of Spain. ${ }^{43}$ After the conquest, Alfonso VI used such titles as "emperor established by God over all the nations of Spain" ${ }^{44}$ and "the lord king Alfonso reigning in Toledo and ruling over Christians and pagans of all the kingdoms of Spain." 45 Even more suggestive is the title he is said to have used in an exchange of letters with al-Mutamid ibn Abbad of Seville in 1085 and with the Almoravid general Yusuf ibn Tashufin in 1086: "emperor of the two religions." While the authenticity of these letters has been debated, Angus MacKay and Mu-

${ }^{41}$ His consorts and their children were Constanza, mother of Urraca (heir); Jimena Múñoz (concubine), mother of Elvira (wife of Count Raymond IV of Toulouse, then of Count Fernando Fernández) and Teresa (wife of Henry of Burgundy and mother of Afonso Enriques, first king of Portugal); Zaida (concubine then wife, baptized Isabel), mother of Sancho; Isabel, mother of Sancha (wife of Count Rodrigo) and Elvira (wife of Duke Roger II of Sicily). His wives Inés, Berta, and Beatriz were childless.

${ }^{42}$ For issues of legitimacy and the portal sculpture at San Isidoro, see my "Un nuevo contexto."

${ }^{43}$ For studies of this event examining the importance of Toledo, see the Estudios sobre Alfonso VI y la reconquista de Toledo, 2 vols. (Toledo, 1987-88). Bernard F. Reilly, The Kingdom of León-Castilla under King Alfonso VI, 1065-1109 (Princeton, N.J., 1988), pp. 135 and 173-74, following Josiah Cox Russell, Medieval Regions and Their Cities (Bloomington, Ind., 1972), p. 178, put Toledo's population at twenty-eight thousand, "greater than the combined populations of every major town in the kingdom of León-Castilla.”

${ }^{44}$ Published in Andrés Gambra, Alfonso VI: Cancillería, curia e imperio, Fuentes y Estudios de Historia Leonesa 62-63 (León, 1997-98), pp. 236-37: "Deo constitutus imperator super omnes Spanie nationes."

${ }^{45}$ Ramón Menéndez Pidal, La España del Cid, 2 (Buenos Aires, 1939), pp. 730-31: “regnante rex domno Adefonso in Toleto et imperante christianorum quam et paganorum omnia Hispanie regna.” 
hammad Benaboud give strong arguments that they should be accepted as genuine. ${ }^{46}$ Even if one attributes these grandiloquent titles to propaganda rather than fact, they still indicate how Alfonso's actions were intended to be read.

In the summer of 1109 the dying king went back to the scene of his greatest triumph to proclaim Urraca his successor in Toledo. She is seen drawing attention to the significance of Toledo as the source of her authority in the Historia Compostellana, the early-twelfth-century chronicle of Bishop Gelmírez of Santiago de Compostela: "For it is well known by you and by all those who live in the kingdom of Spain that my father, Emperor Alfonso, when the hour of his death drew near, turned over to me all of his kingdom in Toledo." 47 An anonymous monk at the Leonese royal monastery of Sahagún, writing around 1117, recognized the true weight of that moment when he told of Alfonso's death in "the very noble city that he had won from the power of Ishmaelites and infidels, that is to say, Toledo," continuing that, there in the presence of bishops and "almost all the nobles and counts of Spain, all of them hearing it, he left the lordship of his kingdom to the said doña Urraca, his daughter, which I happened to hear, because I was present there." ${ }^{48}$ By declaring Urraca his heir in Toledo, Alfonso VI used the symbolic power of that ancient royal city to grant her legitimacy as ruler of León-Castile. The significance of Toledo for Urraca was recognized in the mid-thirteenth century by Ibn Khallikan, a judge in Damascus, in his biographical dictionary The Deaths of Famous Men.$^{49} \mathrm{Ibn}$ Khallikan drew on twelfth-century sources for his biogra-

${ }^{46}$ Angus MacKay and Muhammad Benaboud, "The Authenticity of Alfonso VI's Letter to Yusuf ibn Tashufin," Al-Andalus 43 (1978), 233-37; "Alfonso VI of León and Castile, 'al-Imbratur-dhu-1Millatayn," Bulletin of Hispanic Studies 56 (1979), 95-102; and "Yet Again Alfonso VI, 'The Emperor, Lord of (the Adherents of) the Two Faiths, the Most Excellent Ruler': A Rejoinder to Norman Roth," Bulletin of Hispanic Studies 61 (1984), 165-81. Reilly, Alfonso VI, p. 181, n. 74, considers the letters to be "fabrications of Muslim propaganda." Ibn al-Kardabus, writing c. 1190, commented on the dramatic improvement in Alfonso's fortunes after the conquest of Toledo: "When the tyrant Alfonso [VI], may God damn him, took Toledo, he was filled with pride [literally, 'he raised his nose'], for he thought that the reins of al-Andalus were now in his hands. He then launched the cavalry against all the districts until he managed to conquer all the dependencies of Ibn Di-l-Nun and take possession of them.... Alfonso followed the trajectory of the powerful, and he procured for himself the position of the Caesars. He became so familiar with pride that he considered all who walked on the earth as despicable. He took the title of emperor, which in their language is Amir al-Mu'minin [Prince of the Believers], and he began to title himself Emperor of the Two Religions in the documents he issued" (Felipe Maíllo Salgado, ed., Ibn al-Kardabūs, Historia de al-Andalus, Akal Bolsillo 169 [Madrid, 1986], pp. 108-10).

${ }^{47}$ Emma Falque Rey, ed., Historia Compostellana, CCCM 70 (Turnhout, 1988), 1.64.1, p. 102: "Tibi etenim notum est et omnibus Hispanie regnum incolentibus quoniam pater meus imperator Adefonsus, appropinquante sui transitus hora, mihi apud Toletum regnum totum tradidit. ..." For a translation into Spanish, see Emma Falque, Historia Compostelana: Introducción, traducción, notas $e$ indices (Madrid, 1994).

${ }^{48}$ Antonio Ubieto Arteta, ed., Crónicas anónimas de Sahagún, Textos Medievales 75 (Zaragoza, 1987), p. 25: “. . la muy noble çibdad que él avía ganado del poderío de los ismahelitas e ynfieles, conbiene a saver, de Toledo... quasi todos los nobles e condes de Espanna, los quales todos oyéndolo, dexó el señorío de su reino a la dicha donna Hurraca su fixa, la qual cosa me acontesçió oir, porque yo allí era presente." This chronicle, completed c. 1117, survives only in a Romance copy.

${ }^{49}$ Abu Abbas Shams al-Din Ahmad ibn Muhammad ibn Abi Bakr ibn Khallikan, Wafayat al-a yan fi anba abna al-zaman, excerpted in Tom Drury, "The Image of Alfonso VI and His Spain in Arabic Historians" (Ph.D. diss., Princeton University, 1974), pp. 85-88 and 315-26. 
phies of the Muslim rulers al-Mutamid and Yusuf ibn Tashufin in their battles with Alfonso VI. Recounting the Christian king's death from grief after the battle of Uclés (1108) at which many important members of his court and his only son Sancho were killed, Ibn Khallikan says that Alfonso VI "left no successor, except one daughter, upon whom the sovereignty devolved; and she fortified herself in Toledo." ${ }^{50}$ In fact, Urraca spent very little time during her reign in Toledo, but the symbolism of having been named successor in that city carried weight even a century later.

In her patronage Urraca underlined her position as heir through her father to the Visigoths by evoking the fabled city of Toledo with the unprecedented use of polylobed arches and a horseshoe-shaped portal in San Isidoro. Horseshoe-shaped doors, although common in Spain from the seventh through the tenth centuries in Visigothic, Islamic, and Mozarabic architecture, had disappeared by the eleventh century, only to make a brief reappearance at San Isidoro and at the monastery of Silos in the early twelfth century. ${ }^{51}$ Of the seven doors at San Isidoro, only one is horseshoe shaped and elaborated with polylobes (Fig. 8), suggesting that this form carried meaning beyond the purely decorative. This portal was the entrance to the palace area during Urraca's time; only privileged members of society would have been able to pass through. The room beyond the horseshoe door, called the Pantheon since the seventeenth century, ${ }^{52}$ was a liminal space between church and palace, probably the more public area into which courtiers were allowed, rather than the private palace rooms entered through a nearby door topped by a chrismon tympanum (see Fig. 2, doors marked A and

${ }^{50}$ Drury, “The Image of Alfonso VI," p. 326.

${ }^{51}$ At San Juan de la Peña in Aragon, a tenth-century horseshoe doorway was reused in the twelfth century. Recently, Milagros Guardia Pons, "Relire les espaces liturgiques à travers la peinture murale: Le programme iconographique de San Baudelio de Berlanga (Soria)," Les cabiers de Saint Michel de Cuxa 36 (2003), 79-97, redated the horseshoe-shaped door at the monastery of San Baudelio de Berlanga to c. 1100 , which would raise the number of horseshoe-shaped doors from all of twelfthcentury Spain to three. Meyer Schapiro, in his discussion of Silos's Puerta de las Vírgenes in "From Mozarabic to Romanesque at Silos," Art Bulletin 21 (1939), 312-74 (reprinted in Romanesque Art [New York, 1977], pp. 28-101, esp. p. 66, n. 3), did not realize how unusual the horseshoe-shaped doorway was: "That the horseshoe arch was used in Spanish Romanesque churches in the twelfth century is evident from the example of Porqueras, dated in 1182." In fact, Porqueras is an isolated rural site, where the triumphal arch bears only the slightest suggestion of a horseshoe shape. For a recent reassessment of Schapiro's Silos article, see John W. Williams, "Meyer Schapiro in Silos: Pursuing an Iconography of Style," Art Bulletin 85 (2003), 442-68.

${ }^{52}$ The so-called Pantheon has been the most studied aspect of San Isidoro. For a sumnary of his lifetime of studies, see Antonio Viñayo González, San Isidoro de León, panteón de reyes. Albores románicos: Arquitectura, escultura, pintura (León, 1995). Williams, "Evidence" (above, n. 23), pp. 171-84, redated the Pantheon from 1063 to the 1080 s, a date now generally accepted. For the historiography of the Pantheon, see my "Queen as King: Patronage at the Romanesque Church of San Isidoro de León" (Ph.D. diss., University of Pittsburgh, 2000), chap. 3. See also José Luis Senra, "Aproximación a los espacios liturgico-funerarios en Castilla y León: Pórticos y galileas," Gesta 36 (1997), 122-44. For a dissenting view, see Isidro Bango Torviso, "El espacio para enterramientos privilegiados en la arquitectura medieval española," Anuario del Departamento de Historia y Teoría del Arte, Universidad Autónoma de Madrid 4 (1992), 93-132; and Elizabeth Valdez del Álamo, "Ortodoxia y heterodoxia en el estudio de la escultura románica española: Estado de la cuestión," Anuario del Departamento de Historia y Teoría del Arte, Universidad Autónoma de Madrid 9-10 (1997-98), 9-33. 


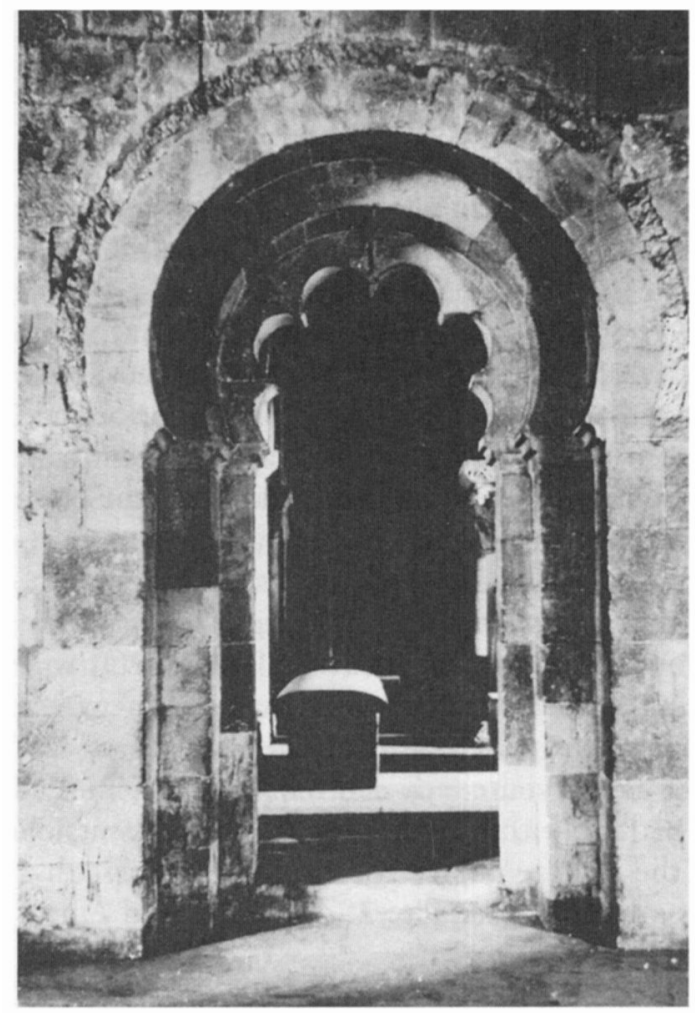

Fig. 8. San Isidoro de Léon, horseshoe-shaped door at west end of church. (Photograph: John Williams. Reproduced by permission.)

B).$^{53}$ The deliberately anachronistic shape of the horseshoe portal linked the present to the past, Urraca to her Visigothic ancestors and their capital in Toledo. ${ }^{54}$ Throughout the Middle Ages, Toledo carried almost mythical meaning as the paradigmatic Visigothic city, and the rulers of León-Castile were considered the direct heirs of the pre-Islamic rulers of the peninsula. ${ }^{55}$ It was this tradition that gave Leonese monarchs, alone of the Christian rulers of Iberia, the right to imperial titles.

Even more extraordinary than the horseshoe door are the polylobes that flank the crossing over the altar, the holiest and most conspicuous site within the church (Fig. 9). The arches at San Isidoro have been taken for granted because polylobes

${ }^{53}$ John Williams has been the only scholar to recognize the palatine nature of this area; see his "León: The Iconography of a Capital," in Cultures of Power: Lordship, Status, and Process in TwelfthCentury Europe, ed. Thomas N. Bisson (Philadelphia, 1995), pp. 231-58. The Leonese palace forms part of my current research on twelfth-century palaces in Spain.

${ }^{54}$ For issues of appropriation and the use of the horseshoe arch in earlier Iberian architecture, see Jerrilynn D. Dodds, Architecture and Ideology in Early Medieval Spain (University Park, Pa., 1990), and "Islam, Christianity, and the Problem of Religious Art," in The Art of Medieval Spain, A.D. 5001200 (New York, 1993), pp. 27-37.

${ }^{55}$ See a recent summary of this idea in Joseph F. O'Callaghan, Reconquest and Crusade in Medieval Spain (Philadelphia, 2003), pp. 4-10. For evocations of Toledo, see Williams, "León: The Iconography of a Capital." 

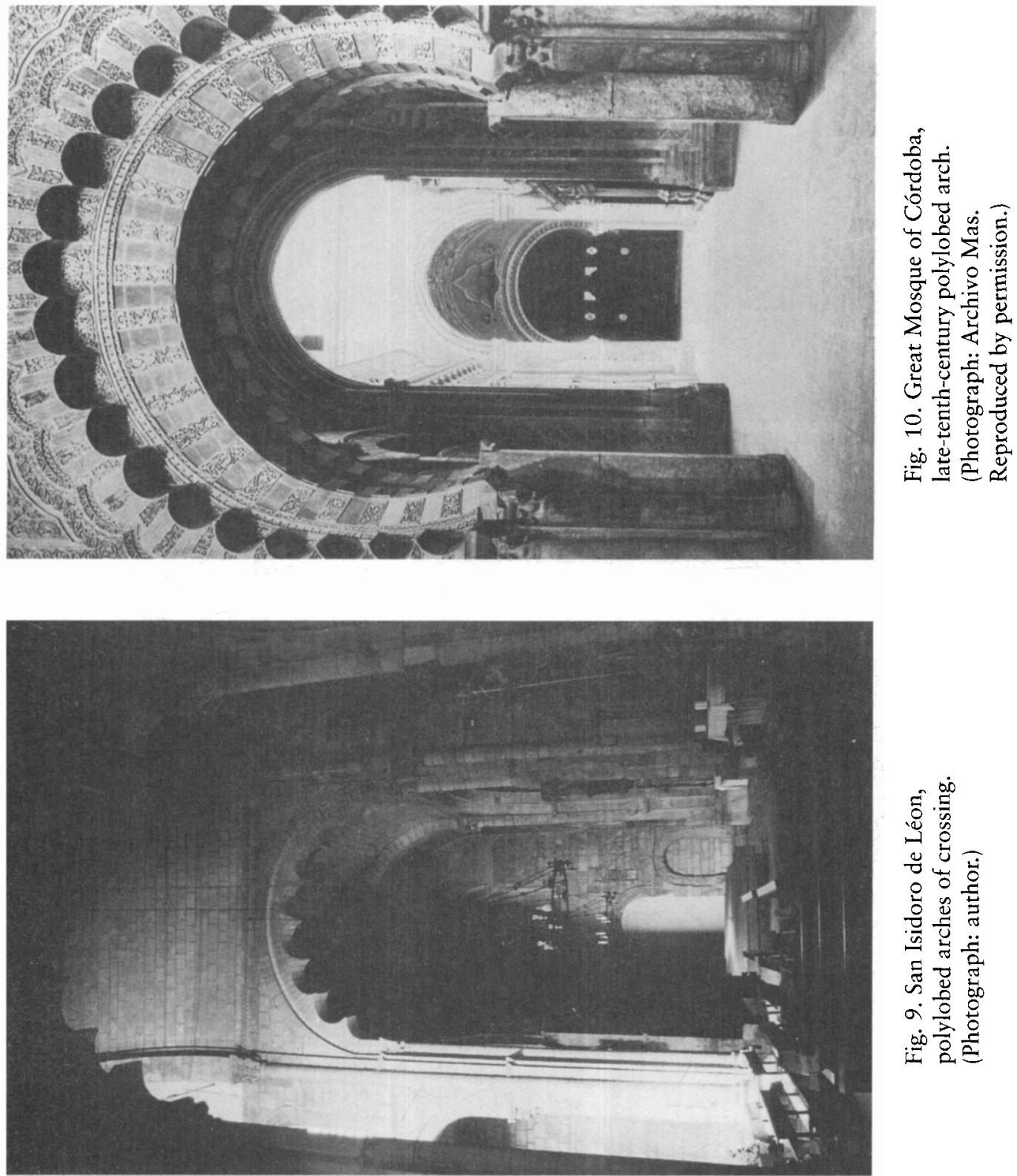

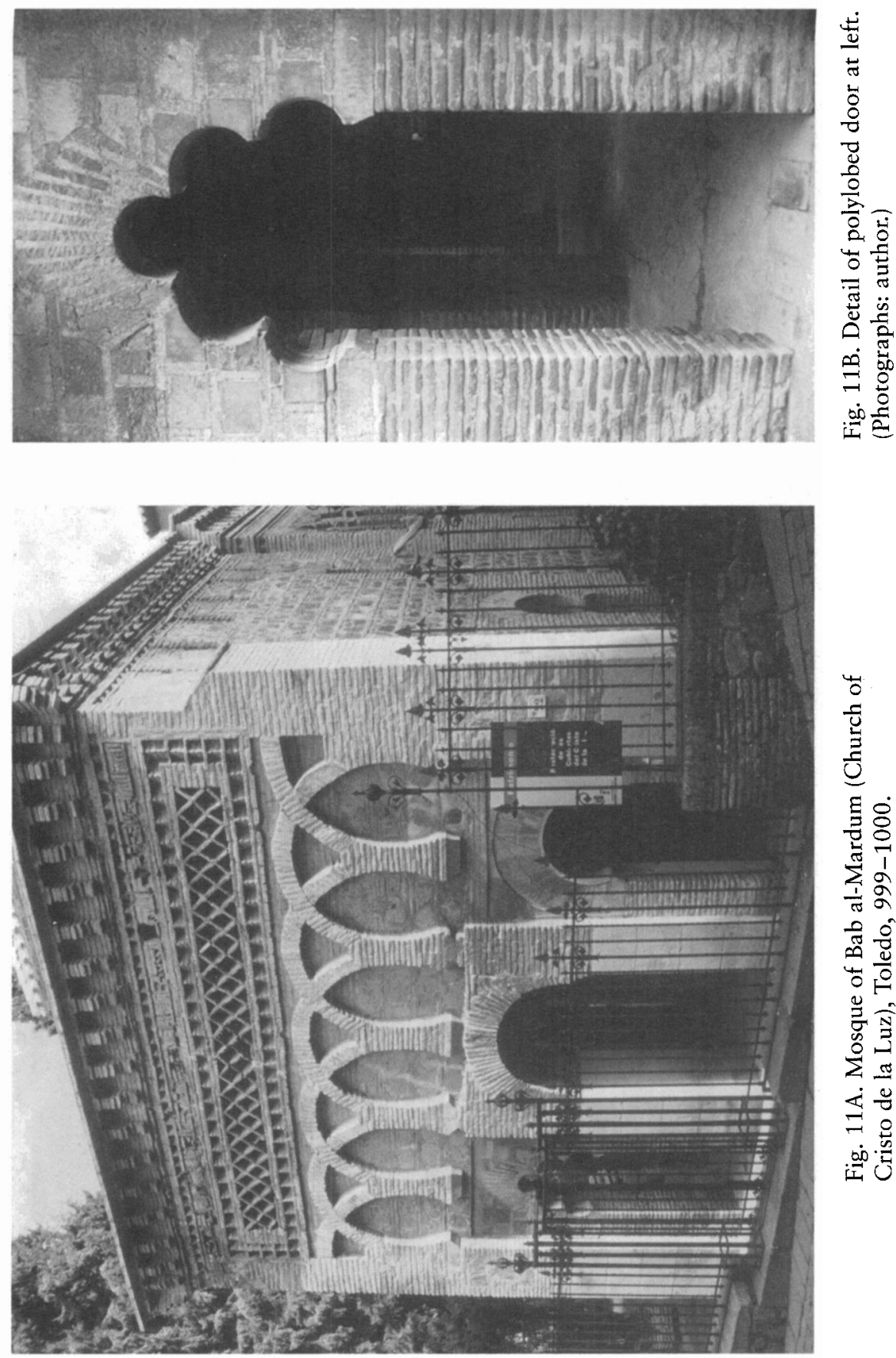

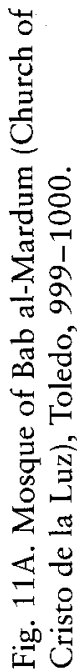


came to be a common decorative feature in later twelfth-century architecture of northern Spain and southern France. However, a thorough study of their history points to San Isidoro as the site of the first major monumental appearance of polylobes in a Christian setting. ${ }^{56}$ This extraordinary occurrence must have responded to an equally remarkable set of circumstances, which I would suggest arose during the reign of Queen Urraca. Polylobed arches, standard in Islamic buildings of the Iberian Peninsula, are likely to have been recognizable in the Middle Ages as Islamic architectural vocabulary. The tenth-century Great Mosque of Córdoba (Fig. 10) is often used as the quintessential example of Islamic architecture, but its privileged position today is due to mere survival: all other major medieval mosques of important Islamic cities of Iberia have been destroyed. For comparative material, we must turn to such buildings as the late-eleventh-century Muslim palace of the Aljafería in Zaragoza ${ }^{57}$ or the tiny mosque of $\mathrm{Bab}$ alMardum in Toledo ${ }^{58}$ (Figs. 11A and B). Polylobed arches such as these are likely to have been used in the Great Mosque of Toledo and copied in the early-twelfthcentury church in León. ${ }^{59}$ The construction of San Isidoro took place only one

${ }^{56}$ Scholars from the earlier part of the twentieth century attempted to trace the polylobed arch to a specific source. See, for example, Émile Mâle, "Les influences arabes dans l'art roman," Revue des deux mondes 7/18 (1923), 311-43 (reprinted in Art et artistes du moyen âge [Paris, 1927]); and Ahmad Fikry, L'art roman du Puy et les influences islamiques (Paris, 1934). However, by 1975 Marcel Durliat, "L'art dans Le Velay," Congrès archéologique de France, Velay 133 (1975), 9-54, had concluded that the Islamic influence could not be traced to one direct source but was simply a part of the contemporary Romanesque vocabulary of the twelfth century. See also Éliane Vergnolle, "La chapelle Saint-Clair au Puy," Congrès archéologique de France, Velay 133 (1975), 314-29, esp. p. 324; and Etelvina Fernández Gónzalez, "El arco: Tradición e influencias islámicas y orientales en el románico del reino de León," Awraq 5-6 (1982-83), 221-42. Linda Seidel, Songs of Glory: The Romanesque Façades of Aquitaine (Chicago, 1981), p. 75, connected the themes of conquest and triumph over Islam to polylobed arches in Aquitaine: "Multilobed arches, like those visible in Mozarabic Spain, form the primary adornment of church entries at Châtres, Aubeterre, and Chalais, among others, in Aquitaine; the cusped archivolts are integrated emblematically into the characteristic triple-arched portal scheme like elegant souvenirs of conquest: the tangible fruits of victory framed by the borrowed symbol of triumph." Although this is an interesting idea, polylobed arches were not used in Mozarabic architecture. Katherine Watson, French Romanesque and Islam: Andalusian Elements in French Architectural Decoration c. 1030-1180, 2 vols., BAR International Series 488 (Oxford, 1989), credits San Isidoro or Santiago de Compostela with the first use of polylobes in a church. The polylobes on the upper level of Santiago's Platerías facade, however, do not appear to be part of the first phase of construction. Other early polylobed arches on the exterior of the ambulatory at Santiago are all but invisible unless one happens to be standing on the roof. San Isidoro's polylobes, on the other hand, decorate the crossing, the most visible part of the church.

${ }^{57}$ For the Aljafería, see Christian Ewert, "Tradiciones omeyas en la arquitectura palatina de la época de los Taifas: La Aljafería de Zaragoza," in España entre el Mediterráneo y el Atlántico: Actas del XXIII congreso internacional de historia del arte, 2 (Granada, 1977), pp. 62-75; his Spanischislamische Systeme sich kreuzender Bögen, 3: Die Aljafería in Zaragoza, pts. 1-2 (Berlin, 1978-80); and Cynthia Robinson, In Praise of Song: The Making of Courtly Culture in al-Andalus and Provence, 1005-1134 A.D., The Medieval and Early Modern Iberian World 15 (Leiden, 2002).

${ }^{58}$ For the use of the polylobed arch in Toledo as part of a "local living tradition of urban architecture" during the twelfth and thirteenth centuries, see David Raizman, "The Church of Santa Cruz and the Beginnings of Mudejar Architecture in Toledo," Gesta 38 (1999), 128-41.

${ }^{59}$ Rocío Sánchez Ameijeiras, "El 'çementerio real' de Alfonso VIII en Las Huelgas de Burgos," Semata 10 (1998), 77-109, esp. p. 109, draws a similar conclusion regarding the evocation of the mosque/cathedral of Toledo by the deliberate use of "vocabulario decorativo almohade" at the royal monastery of Las Huelgas. (I am grateful to James D'Emilio for drawing my attention to this study.) 
generation after Toledo was reconquered and its Great Mosque converted to a cathedral. But conversion did not necessarily mean destruction. ${ }^{60}$ Much of the mosque remained standing until the Gothic cathedral was begun in 1226 , possibly serving as a model for the polylobes at San Isidoro. Still, more important than identifying the direct precedent of the Leonese polylobed arch is recognizing that, at the time this decorative motif was used at San Isidoro, it had never before graced a Christian setting in such an extraordinarily prominent way. At San Isidoro this architectural vocabulary seems intended to claim Visigothic and Islamic Toledo for Urraca through her father, not simply as a conquest but as a reclaiming of what was believed to have belonged by right to her family line. Urraca thus used the public space of her family's church to pay homage to her father while reminding the viewers of her place within that illustrious dynasty. The allusion to Islam is not a straightforward reference to conquest but to the Muslims as one of the peoples of Spain claimed to be under the rule of the emperor, himself heir to the Visigoths, who were remembered as ruling over the whole peninsula. In Alfonso VI's titles, such as "emperor of the two religions," he showed a degree of acceptance of Muslims as his subjects, which, despite the exaggeration of the assertion, gave them a visibility they would not have had if his aim had been only conquest and conversion. Urraca may have used the polylobed arches and horseshoe portal to recall her father's retaking of Toledo and to assume her role as heir to the Visigoths and empress of all Spain. ${ }^{61}$ To add a further layer of meaning, the reference to Toledo may also have responded to the political situation of the day. Archbishop Bernard of Toledo, primate of Iberia, was one of Urraca's most powerful allies. Polylobed arches linked her new church with his, as her politics, discussed below, linked León with Toledo.

\section{The Evocation of Santiago de Compostela}

The polylobed arches of San Isidoro are located within the transept, which was added by Queen Urraca to the simple construction begun by her aunt in the 1090s. The transept associated her church with the other most important ecclesiastical center of her day, Santiago de Compostela. Urraca's enlargement of San Isidoro

${ }^{60}$ The thirteenth-century chronicler and archbishop of Toledo Rodrigo Jiménez de Rada did not speak of tearing down the mosque. Rather, he stated that an altar was set up so that the building could be purified, and bells were hung in the minaret as a visible and audible sign that the existing building was now Christian (Juan Fernández Valverde, ed., Roderici Ximenii de Rada Historia de rebus Hispanie sive Historia Gothica, CCCM 72 [Turnhout, 1987], pp. 137-38). See Julie A. Harris, "Mosque to Church Conversions in the Spanish Reconquest," Medieval Encounters: Jewish, Christian and Muslim Culture in Confluence and Dialogue 3 (1997), 158-72, esp. p. 159.

${ }^{61}$ In a charter of 1110 , Urraca ceded a large stretch of borderlands to her half sister, Teresa, ruler of the region of Portugal, who was then obliged to see it populated. Urraca's obligation was "to provide help and to defend [the land] against Moors and Christians" (Ruiz Albi, La reina doña Urraca, pp. 374-76: "Et que sic ista honor que la regina da ad germana quomodo et altera que illa tenet qulia adiuuet ad anparar et defender contra mauros et christianos per fe sine malo engano et herma et populata, quomodo bona germana ad bona germana, et que non colia suo uassallo cum sua honore aut aleiuoso (qui noluerit exconduzer cum iuditio directo"). See also Monterde Albiac, Diplomatario de la reina Urraca, pp. 42-43. 
involved a radical reconception of its function from the palatine chapel of her grandparents and aunt to a pilgrimage site marked by a projecting transept. The queen took advantage of the fact that León happened to be on the pilgrimage route to Santiago in order to tie her church to that celebrated site. Instead of simply completing the church following her aunt's design, archaeological evidence demonstrates that the newly built east end was dismantled in order to make way for a transept. This gave the Church of San Isidoro a more dominating urban presence, and it provided a second set of doors on the side of the church that opened out toward the city, making Isidore's relics more accessible to pilgrims. In Spanish Romanesque architecture, only Santiago had a projecting transept earlier than San Isidoro, ${ }^{62}$ and it appears that Urraca intended her church to make reference to that most famous of pilgrimage churches. She did this by bringing to León masons and sculptors who had built the east end of Santiago and setting them to work on the new transept of San Isidoro. The hand of a Compostelan master trained in the Toulousan style of sculpture has long been recognized on the south transept portal of San Isidoro, and we can also identify work by other members of the Compostelan team in certain capitals, metopes, and the crossbow-shaped mason's mark. ${ }^{63}$

Urraca's close association with Santiago de Compostela during its initial period of construction helps to explain her decision to alter the design of San Isidoro. Her reign in Galicia (1089-1109) overlapped with the early phase of construction (c. 1075-1110) of the magnificent cathedral at Compostela, built to accommodate and encourage the ever-increasing surge of pilgrims. ${ }^{64}$ By the time Urraca was nine years old, she was already betrothed or married to her mother's cousin, Count Raimundo of Burgundy. ${ }^{65}$ Together they ruled over the realm of Galicia in north-

${ }^{62}$ The date of the transepted church of Santo Domingo de Silos has been a source of scholarly contention, but the problem has been convincingly resolved by José Luis Senra, "Arquitectura y escultura en los grandes monasterios benedictinos de Castilla y León (1073-1157)" (Ph.D. diss., Universidad Autónoma de Madrid, 1997), p. 956, who dates the upper church and transept of Silos to the 1130s. See also his "Santo Domingo de Silos: New Interpretive Suggestions for the Medieval Church," in Church, State, Vellum, and Stone, ed. Martin and Harris (above, n. 18), pp. 335-81.

${ }^{63}$ On the Compostelan workshop in León see my "Reading the Walls" (above, n. 18).

${ }^{64}$ For the construction of the pilgrimage church at Compostela, see especially Serafín Moralejo Álvarez, "Notas para una revisión de la obra de K. J. Conant," in Kenneth John Conant, Arquitectura románica da catedral de Santiago de Compostela, trans. Justo G. Beramendi (Santiago de Compostela, 1983), pp. 221-36, and his "Patronazgo artístico del arzobispo Gelmírez (1100-1140): Su reflejo en la obra e imagen de Santiago," in Pistoia e il Cammino di Santiago: Una dimensione europea nella Toscana medioevale, ed. Lucia Gai (Naples, 1987), pp. 245-72 (both reprinted in Patrimonio artistico); John Williams, "La arquitectura del Camino de Santiago," Compostellanum 29 (1984), 23965; Isidro Bango Torviso, "Las llamadas 'Iglesias de peregrinación' o el arquetipo de un estilo," in Arte y ciudad: Ámbitos medieval, moderno y contemporáneo, ed. María Victoria Carballo-Calero (Santiago de Compostela, 2000), pp. 233-65; Karen Rose Mathews, “'They Wished to Destroy the Temple of God': Responses to Diego Gelmirez's Cathedral Construction in Santiago de Compostela, 1100-1140" (Ph.D. diss., University of Chicago, 1995); and Barbara Abou-el-Haj, "Santiago de Compostela in the Time of Diego Gelmírez," Gesta 36 (1997), 165-79.

${ }^{65}$ Reilly, Alfonso VI (above, n. 43), p. 217. If it were indeed a marriage, it would have been in name only until Urraca reached majority at the age of twelve. For Urraca's first husband, see Bernard F. Reilly, "Assessing the French Influence in Medieval León-Castilla: The Case of Count Raimundo of Burgundy, 1087-1107," in Church, State, Vellum, and Stone, ed. Martin and Harris, pp. 85-109. 
western Spain until Raimundo's death in 1107 , when Urraca became sole ruler. That year, she signed a donation to the Cathedral of Santiago as "the princess domna Urraca, daughter of the emperor Alfonso, and ruler (domina) of all Galicia." ${ }_{66}$ At her father's death, Urraca inherited the rest of León-Castile and became the ruler of the largest Christian kingdom in Iberia. ${ }^{67}$ San Isidoro's new projecting transept changed its identity from a private palace chapel to a public pilgrimage site, visually connecting it not only to Santiago but also to important pilgrimage churches of France, among them Saint-Sernin in Toulouse, Saint-Martin in Tours, and Saint-Martial in Limoges.

\section{The Decisive Moment: 1117}

A confluence of events in 1117 suggests that this may have been the definitive point for the construction of a transept with polylobed arches at San Isidoro. At the end of 1116 the queen had granted control over Toledo to her eleven-year-old son, the future Alfonso VII. She removed him from the hands of Bishop Gelmírez of Santiago, under whose charge he had been to this point, and gave him into the care of her longtime ally, Archbishop Bernard of Toledo. With this action Urraca achieved the dual goal of neutralizing her son as a threat to her throne while claiming Toledo for her line. ${ }^{68}$ In 1117 Urraca made a generous donation to San Isidoro that included the monastery of San Salvador de León, with all its dependent villages, churches, monasteries, inheritances, and possessions. ${ }^{69}$ Although not specified as such, this rich source of income could have been used to subsidize construction. Urraca stated that she was providing for the future of the church, reiterating an unusual three times that her donation was for the clerics both of the present and of the future San Isidoro: "I give this to you for the remission of my sins and those of my relatives and so that you will always remember me and them, both you present today and those who will take charge of the Church of San Isidoro after you. In prayer and charity, your memory of us will always live, once the burden of my flesh has passed." ${ }^{70}$ Here the queen laid out two important

${ }^{66}$ Lucas Álvarez, Tumbo A, pp. 176-77: "infanta domna Urraca, Adefonsi imperatoris filia et totius Gallecie domina." See also Manuel Recuero Astray, María Ángeles Rodríguez Prieto, and Paz Romero Portilla, Documentos medievales del reino de Galicia: Doña Urraca (1095-1126) (Santa Comba, 2002), p. 18: "infanta domna Urraka, totius Galletie domna et imperatoris domni Adefonsi filia et Constantiae reginae nata."

${ }^{67}$ Reilly, Queen Urraca (above, n. 4), p. 280, put the total population ruled by Urraca at roughly one million.

${ }^{68}$ By making her son and his men responsible for Toledo, Urraca effectively took the city back from her estranged second husband, Alfonso el Batallador, who had wrested Toledo from her control in 1111. Although el Batallador continued to sign his documents claiming the rule of Toledo intermittently for some years, Reilly (Queen Urraca, p. 126) points out "there is no trustworthy evidence that he ever exercised authority in the city" after 1117.

${ }^{69}$ Martín López, Documentos (above, n. 16), pp. 40-42; Monterde Albiac, Diplomatario de la reina Urraca, pp. 175-78; Ruiz Albi, La reina doña Urraca, pp. 492-94.

${ }^{70}$ As in n. 69. "Concedo illud uobis ob remisionem pecatorum meorum et meorum parentorum ut et me et eos semper in memoriam habeatis tam uos presentes quam etiam illi qui eidem ecclesiae Sancti Isidori post uos ministraverint et in oratione et elemosina uestra memoria nostri iam exacto onere meae carnis semper uiuat." 
reasons for her patronage of San Isidoro: remission of sins and permanence of memory, made concrete in a site designed to last forever. The income from all the property in this donation could have guaranteed payment to the stonemasons then working on the church for many years to come. Urraca's nearly continuous presence in León in 1117 together with her lavish donation suggests that this was a key moment in the construction of San Isidoro. ${ }^{71}$ During this period, construction of the church must have progressed rapidly, given the evidence provided by the multiplicity of mason's marks. ${ }^{72}$ In political terms the Church of San Isidoro did not have the importance of other sites to which Urraca made multiple donations, such as the cathedrals of Toledo, Santiago, and León and the Burgundian monastery of Cluny. With those gifts the queen forged alliances with powerful bishops and abbots, the major political-religious figures of her day. But the pattern of her other donations makes Urraca's 1117 gift to San Isidoro even more significant, for no alliance needed to be established there. Rather, this was a physical manifestation of her dynasty at the heart of her kingdom. Funding for construction was necessary, but not the repeated gifts to maintain the loyalty of wavering allies that we see at other sites.

The year 1117 was also a turning point in Urraca's reign, which had been greatly troubled until then. When Urraca came to the throne in 1109, she allied herself with the warlike king of neighboring Aragon. By marrying Alfonso I (known as el Batallador, "the Battler," for his prowess at war), Urraca was able to contain him until she had built up the military strength to fight him. ${ }^{73}$ The marriage had been arranged by Urraca's father, but we can safely conjecture that she participated in the decision..$^{74} \mathrm{~A}$ widow of twenty-nine and the mother of two children, Urraca had already proven herself as domina of Galicia. She was the sole ruler in Spain who could make a claim to imperial heritage through the Visigoths; and while el Batallador was a strong king in his own right, he could call himself emperor only while married to Urraca. ${ }^{75}$ As a strategy for staying on the throne, the marriage was successful for Urraca, who continued to rule until her death seventeen years later. But as a marriage per se, the union was a disaster; peace between the two

${ }^{71}$ Like any medieval monarch, Urraca spent much of the year traveling throughout her kingdom. She normally wintered in León, but 1117 found her there from March through May and again from July through September (Reilly, Queen Urraca, p. 123). Although there are no notices after September, logic dictates that she was again in León for her annual Christmas court.

${ }_{72}$ There are more than forty different mason's marks and many hundreds of examples throughout the limestone masonry that help to clarify the phases of construction. They also provide a glimpse of medieval workshop practices. For example, eight different marks appear exclusively on piers, while six different marks were assigned exclusively to walls. This division of labor indicates a large number of masons working simultaneously in order for construction to proceed as quickly as possible. For an analysis of San Isidoro's marks, see my "Reading the Walls."

${ }^{73}$ The most thorough study of Alfonso el Batallador's reign is José Ángel Lema Pueyo, Instituciones políticas del reinado de Alfonso I el Batallador, rey de Aragón y Pamplona (1104-1134) (Bilbao, 1997). For the marriage agreement, see pp. 47-48; also Reilly, Queen Urraca, p. 59.

74 José María Ramos y Loscertales, "La sucesión del rey Alfonso VI," Anuario de bistoria del derecho español 13 (1936-41), 36-99.

${ }^{75}$ Lema Pueyo, Instituciones políticas, pp. 48-52. 
surfaced only intermittently during years of hostilities. ${ }^{76}$ Four years of acrimonious separations, pitched battles, and short-lived reconciliations led at last to a decisive break in 1113 and all-out war, in which each sought to gain sovereignty over the lands of the other. The Historia Compostellana provides a vivid description of Urraca fighting her estranged husband: “... and she did not stay in castles or cities but lived in campaign tents. She gathered a large and valiant army and chased after the cruel Aragonese kinglet. She set up camp, with tents and army around, and besieged him in Carrión, and she kept him under siege for a long time." 77 However, neither ruler was strong enough to defeat the other, and so, in 1117, Urraca negotiated a three-year truce that, renewed in 1120 and again in 1123, would last until the end of her reign. ${ }^{78}$ This standoff would be represented by later chroniclers as continuous civil war, though in fact the last nine years of Urraca's reign were as peaceful as any decade in the history of León-Castile.

Monarchy in the Middle Ages was an institution that took for granted the ability to marshal an army, and I would suggest that Queen Urraca could not have ruled her kingdom successfully if she had not been accepted as both queen regnant and military leader. Evidence of the military character of the queen can be found over and over again in her charters. In a donation of 1116, a noblewoman declared that her son had been killed in battle against the queen: "filius meus Didacus Petriz in guerram et contrarietatem regine mortuus fuit. ..."79 Should we read this statement literally, or should we take it as an example of synecdoche, in which the figure of the queen stands for her armies? The brevity of the declaration means that we cannot know. But I would contend that the question arises only because the ruler is a woman. If the charter declared that the son had been killed fighting the king, we would be unlikely even to question the statement.

From her separation from Alfonso el Batallador until her death in 1126, Urraca was the sole ruler ${ }^{80}$ of the most powerful Christian kingdom in Hispania, acting more as a king than a queen. No queen in Spain had ever coined money in her own name before Urraca, and none would do so again for more than 150 years. ${ }^{81}$

${ }^{76} \mathrm{Had}$ children been born to Urraca and Alfonso, they might have been forced to reach some sort of accord. Reilly, Queen Urraca, p. 61, states, "For the queen, then, the failure of the marriage's chief purpose [i.e., an heir to the combined thrones of León-Castile and Aragon] must inevitably have led to a search for other avenues to restore her authority." My contention is that the construction of San Isidoro was just such an avenue.

${ }^{77}$ Falque Rey, Historia Compostellana 1.73.4, p. 114: “. . . et iam non in castellis seu ciuitatibus morabatur sed in tabernaculis habitabat, et congregauit exercitum magnum ualde et fortem et persecuta est crudelem regulum Aragonensem; castra sua et tentoria suumque exercitum circumponens eum Carrione obsedit obsessumque diuturno tempore tenuit."

${ }^{78}$ According to Reilly, Queen Urraca, p. 122, the truce was made at the Council of Burgos in February 1117. See Fidel Fita, "Concilio nacional de Burgos (18 febrero 1117): Texto inédito," Boletín de la Real Academia de la Historia 48 (1906), 387-407, esp. pp. 394-99.

${ }^{79}$ Monterde Albiac, Diplomatario de la reina Urraca, pp. 153-54.

${ }^{80}$ Although Urraca did, on certain occasions, sign charters in conjunction with her son, the future Alfonso VII did not become king of León-Castile until her death.

${ }^{81}$ Mercedes Rueda, Primeras acuñaciones de Castilla y León, Monografías de Arqueología Medieval 1 (Salamanca, 1991), p. 52. See also Alan M. Stahl, "Coinage in the Name of Medieval Women," in Medieval Women and the Sources of Medieval History, ed. Joel T. Rosenthal (Athens, Ga., 1990), pp. 321-41. 
In fact, Urraca was the first monarch of either sex in León-Castile whose coins present the ruler's portrait. ${ }^{82}$ One of her coins minted in Toledo (the inscription on the reverse reads "TOLETUO") shows a bust of the queen wearing a diadem (Fig. 12). The inscription reads "URACA RE." It should be noted that the (deliberately?) ambiguous abbreviation "RE" leaves open the completion of the word as either regina or rex. We know from charters that Urraca traveled with her troops. In a donation of 1110 Urraca's notary stated explicitly that when the charter was written, "the queen left Nájera with her army heading for Zaragoza," where there was to be a great battle. ${ }^{83}$ She even went so far as to refer to herself as king in a document of 1121, promising Archbishop Gelmírez of Santiago that she would be to him "a faithful lady and friend, as a good king (bonus rex) to his good archbishop, for my whole life." ${ }^{4}$

Queen Urraca consistently went after funding for her troops, guaranteeing their loyalty and support. ${ }^{85}$ Pressed for payment for her soldiers, Urraca availed herself of land she inherited through the infantazgo as a royal princess and of land that was her patrimony as ruling monarch. In 1112, for example, Urraca gave property from the royal demesne to the Cathedral of Lugo from which she received in return "one hundred silver marks in sacred altar ornaments . . . in order to give payment to my soldiers." ${ }^{86}$ Clearly she knew the value of maintaining an army's loyalty by providing a regular salary. In the same donation Urraca asked the Virgin Mary to help her hold onto and pacify the kingdom that she had inherited from her father. ${ }^{87}$ Also in 1112 Urraca received gold and silver from the Cathedral of Oviedo in exchange for lands and property, specifying that "we do this for the protection of

${ }^{82}$ The use of Urraca's portrait may have been inspired by her husband's coinage, as Aragonese examples had begun to display the ruler's image slightly earlier. However, Aragonese coins showed the king exclusively in profile, whereas Urraca's coinage includes both bust and profile images of the queen. See F. Álvarez Burgos, Catálogo de la moneda medieval castellano-leonesa: Siglos XI al XV, Catálogo General de las Monedas Españoles 3 (Madrid, 1998), pp. 16-21.

83 "Regina exiuit cum suo exercitu per a Cesaraugustam medio augusto" as transcribed by both Monterde Albiac, Diplomatario de la reina Urraca, pp. 35-36, and Ruiz Albi, La reina doña Urraca, pp. 370-71 (my emphasis). Reilly, Alfonso VI, p. 73, points out that her father, Alfonso VI, "sometimes led his own armies into battle," indicating that not even a ruler with great fame as a warrior was always at the head of his troops.

${ }^{84}$ Ruiz Albi, La reina doña Urraca, pp. 552-53: “. . . sim vobis fidelis domina et amica, sicut bonus rex suo bono archiepiscopo in tota vita mea." See also Monterde Albiac, Diplomatario de la reina Urraca, pp. 247-48.

${ }^{85}$ As any successful king would have done, as well. However, this would, in fact, become the seed that grew into Urraca's mala fama in the early modern period, in which she was said to have been struck dead while robbing San Isidoro of its treasures. I have traced the origins of this legend in "De gran prudencia" (above, n. 9).

${ }^{86}$ Ruiz Albi, La reina doña Urraca, pp. 412-14: "Et accipio de gazofilatio beate Marie marcas argenti $\mathrm{Cm}$. de sacratis ornamentis altaris eiusdem Uirginis ut reddam donatiua militibus meis pro quibus omnibus et uillam de Gonterici ... concedo." See also Monterde Albiac, Diplomatario de la reina Urraca, pp. 81-82.

${ }^{87}$ As in n. 86: "Nunc autem domina et regina Ihesu Christi mater Maria rogo ut acceptabilem abeas hanc licet paruam oblationem ac deferas mea suspiria et lacrimas et gemitus ante conspectum diuine maiestatis quatinus pia tua intercessio auxilietur mihi ad inquirendum regnum et pacifice possidendum patris mei et sis mihi clipeus et protectio in hoc seculo et in die tremendi iudicii." 

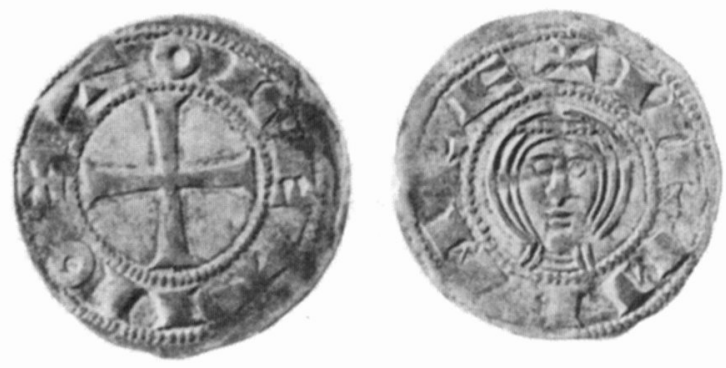

Fig. 12. Coin of Queen Urraca minted in Toledo, 1109-26.

(Photograph: Museo Arqueológico de Madrid.

Reproduced by permission.)

our kingdom against the great infestation of foreign peoples in times of war." 88 Given the date, this reference to the enemy could as easily refer to the Aragonese subjects of her estranged husband as to the Muslims in the south of the Iberian Peninsula.

Urraca's active role as a military leader is neatly summed up by Ibn al-Kardabus (the Cordobese), a Muslim historian writing toward the end of the twelfth century: ${ }^{89}$

Alfonso [VI] left no son but a daughter who succeeded him in power for some time, consolidating it solidly and strongly. Later she feared that one of the Christian or Muslim kings might try to marry her, but her love won out, and thus she secretly sent to Ibn Ramiro [Alfonso el Batallador, literally "the son of Ramiro"], saying that he should marry her. So the marriage was carried out, but without happiness or success, as they had spent but a short time together when a great enmity arose between the two. They then separated in the worst of conditions.

Ibn Ramiro left and gathered the people of his nation; she meanwhile gathered hers as well. [Ibn Ramiro] headed for her, and she started against him and did not turn back. Then they fought for some time, and the war between them was intense, until God gave her power over him; thus she inflicted on him a great defeat from which he could not recover. He lost in it more than three thousand of his valiant men. ${ }^{90}$

Ibn al-Kardabus gives us some clues not found in the Christian sources for understanding Urraca's reign. According to this chronicler, she took an active role in the choice of her second husband. None of the Christian chronicles indicate that

${ }^{88}$ Ruiz Albi, La reina doña Urraca, pp. 398-405: "Et hoc fecimus pre nimia infestatione gentis extranee in tempore belli ad tuicionem regni nostri." See also Monterde Albiac, Diplomatario de la reina Urraca, pp. 64-71. This charter forms part of Bishop Pelayo of Oviedo's Liber testamentorum and, as such, may not be completely reliable. Whether or not the specifics of this donation can be verified, this charter speaks to the common occurrence of a ruler's exchanging property for gold with which to support the army.

${ }^{89}$ Ahmad Muter al-'Abbad, ed., Historia de al-Andalus por Ibn al-Kardabus y su description por Ibn al-Sabbath (Madrid, 1971). For a Spanish translation, see Maíllo Salgado, Historia de al-Andalus (above, n. 46).

${ }^{90}$ Maíllo Salgado, Historia de al-Andalus, pp. 140-41. 
her hand might have been sought by a Muslim ruler, but it seems plausible. Urraca's father had taken a Muslim concubine, Zaida, later baptized Isabel, whom he married in order to give legitimacy to his only son, Sancho. ${ }^{91} \mathrm{Ibn}$ al-Kardabus also underscored Urraca's valor in heading out to meet her estranged husband's armies by stating that "she did not turn back," despite the forces arrayed against her. However, the chronicler can also be seen making use of this story in order to denigrate Alfonso el Batallador, who was, in fact, a mighty warrior, highly successful in his many battles against Muslim kingdoms. El Batallador's defeat at the hands of a woman must have been a tale gleefully repeated by his enemies, whether true or not. Despite the polemical nature of the chronicle, it provides another perspective from which we can see that Urraca's military character was an accepted part of her role as queen regnant and one of her successful strategies for rulership, in addition to patronage and evoking the memory of her father.

The most detailed, if not necessarily the most accurate, descriptions of Queen Urraca acting as a military leader are provided by the Historia Compostellana. Bishop Gelmírez's chronicle includes a telling anecdote of a rebellion against queen and bishop during Urraca's visit to Santiago in 1117.92 After a vivid description of the townspeople attacking and insulting Urraca, the story ends with the rebels thinking the better of their actions and seeking to make peace with the queen. Urraca feigned to accept the suit for peace in order to leave the city safely, whereupon she ordered a declaration of war. She commanded the bishop and his army to besiege the city. Further, "the queen also sent her legates to all parts and ordered everyone, both consuls and princes, knights and foot soldiers, to come to the siege and destruction of Compostela." 93 The chronicler goes on to detail the specific locations at which she set her eldest son and each of her vassals as they commanded segments of her siege. The city could not withstand such a tremendous force, and it surrendered to the queen. Urraca's actions were those of a successful, if ruthless, monarch and military leader who organized her troops in battle in order to dominate her rebellious subjects. The year 1117 was indeed a pivotal moment in Urraca's reign, the moment at which her fortunes shifted from struggling ruler to dominant monarch. The queen's triumph over the Compostelan rebellion in the summer set the stage for her munificent donation to San Isidoro in September 1117.

\section{Reigning Queens of The Twelfth Century}

The significance of Urraca's politics and patronage becomes clearer when she is measured against other reigning queens. Patterns of rulership and patronage are shared by Urraca, Melisende, and Matilda, although individual historical circumstances determined the differing outcomes of the three. Baldwin II (d. 1131) of

\footnotetext{
${ }^{91}$ See the study by Julio Pérez Llamazares, “Zaida," Hidalgo 9 (March-April 1955), 273-80.

${ }_{92}$ On the revolt of 1117, see Luis Vázquez de Parga, "La revolución comunal de Compostela en los años 1116 y 1117," Anuario de historia del derecho español 16 (1945), 685-703.

${ }^{93}$ Falque Rey, Historia Compostellana 1.116.3, p. 214: "Regina quoque mittit legatos suos circumquaque et omnes tam consules et principes quam milites et pedites precepit uenire ad obsidionem et ad destructionem Compostelle."
} 
the Latin Kingdom of Jerusalem had no sons, so he chose to make his daughter Melisende his successor and his son-in-law Fulk of Anjou the king, a decision for which he sought and obtained the agreement of the magnates of his court. ${ }^{94} \mathrm{In}$ 1129 Melisende signed herself "Melisende, daughter of the king and heir to the kingdom of Jerusalem." 95 Then, just before his death, Baldwin II named as corulers Melisende, Fulk, and their two-year-old son in an attempt to guarantee hereditary rule by his own line. ${ }^{96}$ In effect, both Melisende and Fulk were to be regents for their son, much to Fulk's displeasure. He attempted to wrest control of the throne from Melisende in order to rule alone, but the magnates loyal to the queen supported her in this crucial moment, and the royal couple acted as corulers thereafter. ${ }^{97}$ Melisende came into full power at Fulk's death in 1143. She and her son Baldwin III, then thirteen, were crowned at the Church of the Holy Sepulchre. Presumably, she was to have served as regent until Baldwin came of age two years later. Instead, she refused to give up the throne, ruling for nine years, which led finally to armed conflict with her son. He forced her from power in 1152 and prevented her from playing an active political role through the end of her life in $1161 . .^{98}$ Baldwin III outlived his mother by just two years.

Melisende's name may be familiar as the owner of a sumptuous illuminated Psalter with bejeweled ivory covers (Fig. 13), but other examples of her patronage

${ }^{94}$ See Bernard Hamilton, "Women in the Crusader States: The Queens of Jerusalem," in Medieval Women, ed. Derek Baker, Studies in Church History, Subsidia 1 (Oxford, 1978), pp. 143-74; Hans Eberhard Mayer, "Studies in the History of Queen Melisende," Dumbarton Oaks Papers 26 (1972), 95-182 (reprinted in his Probleme des lateinischen Königreichs Jerusalem, Collected Studies Series 178 [London, 1983]); and his "The Succession to Baldwin II of Jerusalem: English Impact on the East," Dumbarton Oaks Papers 39 (1985), 139-47 (reprinted in his Kings and Lords in the Latin Kingdom of Jerusalem, Collected Studies Series 437 [Aldershot, Eng., 1994]); Sarah Lambert, "Queen or Consort: Rulership and Politics in the Latin East, 1118-1228," in Queens and Queenship, ed. Duggan (above, n. 6), pp. 153-69; and Deborah Gerish, "Shaping the Crown of Gold: Constructions of Royal Identity in the First Kingdom of Jerusalem" (Ph.D. diss., University of California, Santa Barbara, 1999). For representations of Melisende a century after her death, see Jaroslav Folda, "Images of Queen Melisende in Manuscripts of William of Tyre's History of Outremer: 1250-1300," Gesta 32 (1993), 97-112.

${ }^{95}$ Mayer, "The Succession to Baldwin II," p. 144: "Milissenda filia regis et regni lerosolimitani heres."

${ }^{96}$ Fulk of Anjou was the father of Geoffrey Plantagenet, second husband of Matilda of England, making Melisende the stepmother-in-law of Matilda. Fulk's daughter by his first marriage was married to Matilda's brother William, whose death cleared the way for Matilda to inherit the kingdom. Baldwin II sought to prevent his son-in-law's children from a prior marriage from acceding to the throne of Jerusalem, should anything befall his young grandson.

${ }^{97}$ For a discussion of the political reasons behind the revolt of Count Hugh II of Jaffa, which had been blamed on an illicit relationship with Melisende, see Hans Eberhard Mayer, "Angevins versus Normans: The New Men of King Fulk of Jerusalem," Proceedings of the American Philosophical Society 133 (1989), 1-25 (reprinted in Mayer, Kings and Lords).

${ }^{98}$ However, Lambert, "Queen or Consort," pp. 153-69, quotes the reflections by William of Tyre on Melisende at her death, underlining that her husband was not described as reigning and that Melisende continued ruling during the reign of her son: "Transcending the strength of women, the lady queen, Melisende, a prudent woman, discreet above the female sex, had ruled the kingdom with fitting moderation for more than 30 years, during the lifetime of her husband and the reign of her son." 


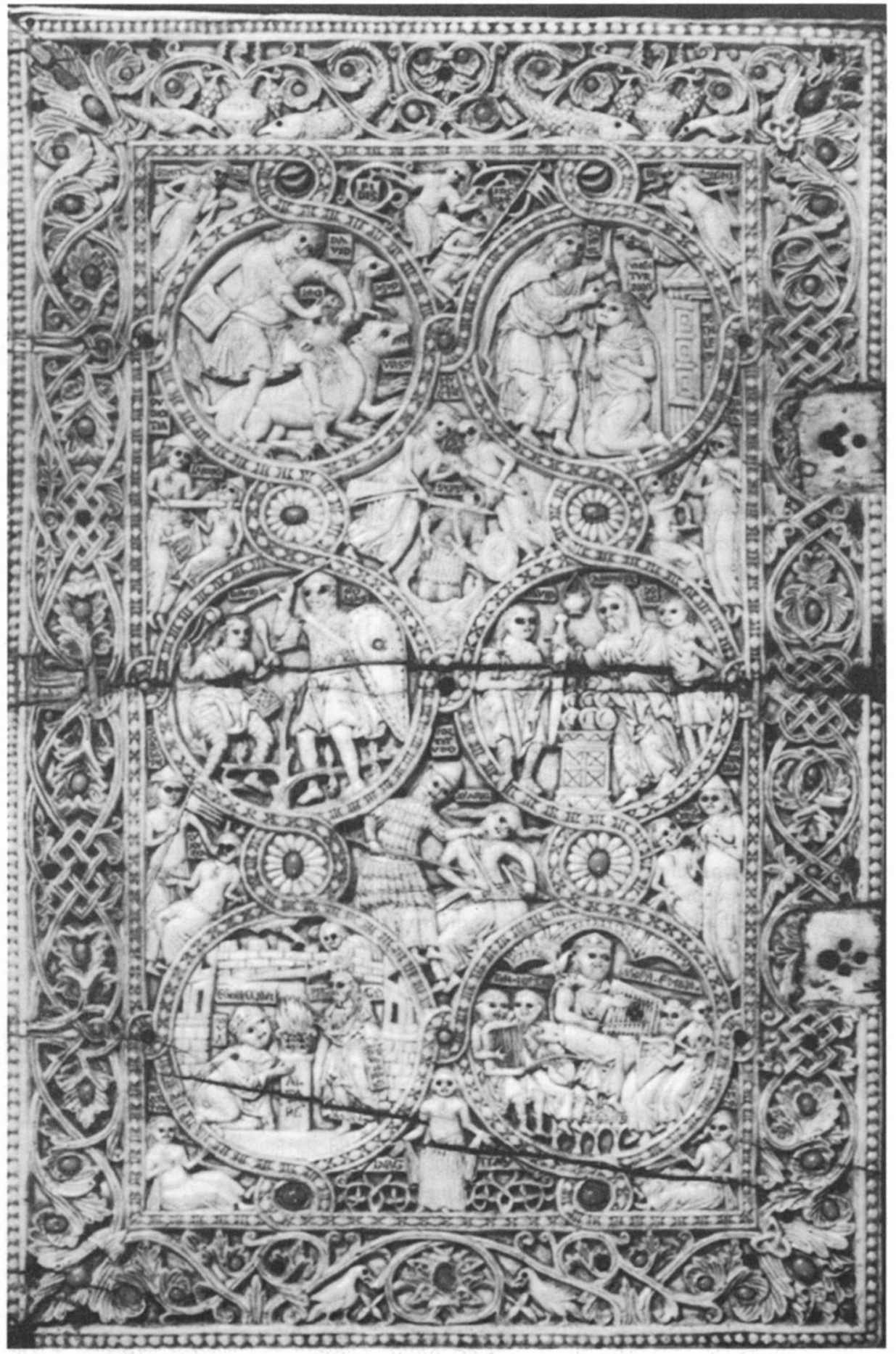

Fig. 13. Melisende Psalter, c. 1135.

London, British Library, MS Egerton 1139.

(Reproduced by permission.) 
are less well known. ${ }^{99}$ The art and architecture she sponsored, though documented especially by Jaroslav Folda, have not been subjected to a thorough examination as part of her overall political strategy, as I attempt to do here with Urraca. Melisende and her husband Fulk were the first Latin monarchs to be crowned in the Church of the Holy Sepulchre. Folda argues that she was the major patron behind its renewed construction in the $1140 \mathrm{~s}$ in preparation for the reconsecration on 15 July 1149, the fiftieth anniversary of the capture of Jerusalem. ${ }^{100}$ Melisende's patronage in the city of Jerusalem included in 1152 a centrally located covered market street known as Malquissinat, "The Street of Evil Cooking," which sold food to pilgrims and travelers. ${ }^{101}$ According to Folda, Melisende may have donated an iron grille around $\mathbf{1 1 4 0}$ as one aspect of her support for the Templum Domini. ${ }^{102}$ This was the Islamic shrine of the Dome of the Rock, considered by the crusaders to be part of Solomon's Temple and consecrated by them as a church. Its image appeared on the Latin rulers' seal, along with the Church of the Holy Sepulchre and the Tower of David, used as the royal palace from the time of Melisende's father. ${ }^{103}$ The grille was designed to surround the rock at the building's center, providing access for pilgrims to the holy site while preventing them from chipping away pieces as souvenirs. In her own day, the queen was lauded by the chronicler William of Tyre for her foundation of the women's monastery at Bethany, where her sister Yvetta was to be abbess. ${ }^{104}$ Her donation to Bethany included

${ }^{99}$ Jaroslav Folda, The Art of the Crusaders in the Holy Land, 1098-1187 (Cambridge, Eng., 1995), pp. 137-59 and 523-27, dates the Psalter and its covers to c. 1135. See also Bianca Kühnel, "The Kingly Statement of the Bookcovers of Queen Melisende's Psalter," in Tesserae: Festschrift für Josef Engemann, Jahrbuch für Antike und Christentum, Ergänzungsband 18 (Münster, 1991), pp. 340-57; and her Crusader Art of the Twelfth Century: A Geographical, an Historical, or an Art Historical Notion? (Berlin, 1994), pp. 67-125. Jean Brodahl, "The Melisende Psalter and Ivories (BL Egerton 1139): An Inquiry into the Status and Collecting of Medieval Art in Early Nineteenth-Century France" (Ph.D. diss., Brown University, 1999), posits the addition of the ivories to the Psalter in the late eighteenth or early nineteenth century. She dates the front ivory to c. 1160 Regensburg or England and considers the back cover a modern copy of the front.

${ }^{100}$ Folda, The Art of the Crusaders, p. 328, calls Melisende "a major political force, ecclesiastical supporter, and artistic patron"; see pp. 130-59, 166-69, 175-253, and 324-28 for her patronage. However, as Robert Ousterhout recently underlined in "Architecture as Relic and the Construction of Sanctity: The Stones of the Holy Sepulchre," Journal of the Society of Architectural Historians 62 (2003), 4-23, frustratingly little can be documented about the building's construction during the crusader period.

${ }^{101}$ Adrian J. Boas, Crusader Archaeology: The Material Culture of the Latin East (London, 1999), p. 52. This study, although useful, demonstrates from the outset the prevailing tendency to ignore reigning queens. In the chronology at the beginning of the book, the reigns of Melisende's father, husband, and son are listed, but she herself does not appear.

${ }^{102}$ Folda, The Art of the Crusaders, pp. 136-37 and 249-53. Segments of the grille, in place until the 1960 s, are now in the Islamic Museum in Jerusalem.

${ }^{103}$ Hans Eberhard Mayer, "Das Siegelwesen in den Kreuzfahrerstaaten," Abhandlungen der Bayerischen Akademie der Wissenschaften, Philosophisch-Historische Klasse, n.s., 83 (Munich, 1978), plate 1, nos. 15 and 16.

${ }^{104}$ Willelmi Tyrensis Archiepiscopi Chronicon, ed. R. B. C. Huygens, CCCM 63-63A (Turnhout, 1986), 15.26. See Hans Eberhard Mayer, Bistümer, Klöster und Stifte im Königreich Jerusalem, Schriften der Monumenta Germaniae Historica 26 (Stuttgart, 1977), pp. 254-57 and 372-402; his "Fontevrault und Bethanien: Kirchliches Leben in Anjou und Jerusalem im 12. Jahrhundert," Zeitschrift für Kirchengeschichte 102 (1991), 14-44 (reprinted in Mayer, Kings and Lords); and Folda, The Art of the Crusaders, pp. 131-33. 
extensive gifts of lands, a fortified building, books, lavish church goods, and vestments. Other recipients of Melisende's generosity in Jerusalem were the churches of St. Anne (where her sister had been a nun before going to Bethany), St. James, and St. Samuel. ${ }^{105}$ At Gethsemane, Melisende commissioned a tomb for herself in the Church of the Tomb of the Virgin in Jehosaphat, where her mother already lay at rest and where she would be buried in $1161 .{ }^{106}$ One can recognize in this brief account of Melisende's patronage her interest in sites with connections to her family and those of importance within her capital city, characteristics also noted in Urraca's patronage.

Just as Urraca and Melisende were named their fathers' heirs during the kings' lifetime, so was Matilda of England. Matilda (or Maud) never fully ruled the England of her father, Henry I, although certain regions were loyal to her. ${ }^{107}$ Known as Empress Matilda due to her first marriage (1114-25) to Emperor Henry V of Germany, which ended with his death and without issue, she continued to style herself "imperatrix" along with other titles after her return to England. Her father's barons had sworn to support her as reigning queen in 1127, following the death of Henry's legitimate son and during his childless second marriage. ${ }^{108}$ Gervase of Canterbury recorded that Henry I "made the English princes and magnates take an oath to his daughter, legitimate heir to the English kingdom." ${ }^{109}$ When Henry died in 1135, Matilda's cousin Stephen of Blois, who had sworn to support her, seized the throne. ${ }^{110}$ Stephen's coronation at the hands of the archbishop of Canterbury was his most politically astute move, ultimately one that Matilda never was able to overcome. Her attempt to win the throne began in 1139 when, after a period in which Matilda built up strength and supporters, full civil war erupted. She captured Stephen in 1141 and was crowned "Lady/Ruler of the English" (domina anglorum) at Winchester Cathedral. For almost a year, this seemed to be the turning point, but the culminating moment remained elusive. Matilda was never formally called queen, but she did issue coinage in her own

10.5 Folda, The Art of the Crusaders, pp. 133-37 and 246-51.

${ }^{106}$ Folda, The Art of the Crusaders, pp. 324-28.

107 The most thorough study of Matilda's reign is Marjorie Chibnall, The Empress Matilda: Queen Consort, Queen Mother and Lady of the English (Oxford, 1992). See also C. W. Hollister, "The AngloNorman Succession Debate of 1126: Prelude to Stephen's Anarchy," Journal of Medieval History 1 (1975), 19-39; Karl Leyser, "The Anglo-Norman Succession 1120-1125," Anglo-Norman Studies 13 (1991), 225-41; Carolyn Anderson, "Narrating Matilda, 'Lady of the English,' in the Historia novella, the Gesta Stephani, and Wace's Roman de Rou: The Desire for Land and Order," Clio 29 (1999), 47 67; Jean A. Truax, "Winning over the Londoners: King Stephen, the Empress Matilda, and the Politics of Personality," Haskins Society Journal 8 (1999), 43-61; and B. Weiler, "Kingship, Usurpation and Propaganda in Twelfth-Century Europe," Anglo-Norman Studies 23 (2001), 299-326.

${ }^{108}$ This despite the fact that Henry I is said to have had some twenty illegitimate children. Clearly he considered a legitimate daughter more apt to rule than any number of illegitimate sons.

${ }^{109}$ Gervase of Canterbury, Opera historica, ed. William Stubbs, Rolls Series 73/1 (London, 1879), p. 93: "fecit principes et potentes Angliae adiurare eidem filiae suae et heredibus suis legitimis regnum Angliae." For the different ways chroniclers recorded this moment, see Mayer, "The Succession to Baldwin II," p. 145, n. 37.

${ }^{110}$ Some of Henry's barons objected to Matilda's second marriage in 1128 to the count of Anjou, Geoffrey V Plantagenet, using it as an excuse to break their oath. 
name, the act of a ruling monarch. ${ }^{111}$ Matilda's advantage was lost when her strongest supporter and half brother, Robert, earl of Gloucester, was taken prisoner, and she was compelled to make a hostage exchange of Stephen for Robert. For the next six years Matilda and Stephen held the other off as they ruled in the regions loyal to each, but the conflict came to a head when Robert of Gloucester died in late 1147. The following year Matilda was forced to concede the throne to Stephen. She left England, never to return, but she continued to fight for the right of her line to rule. When King Stephen's elder son died in 1153, Stephen recognized Matilda's son Henry as his heir instead of his own younger son, finally ending the two decades known as the Anarchy. Matilda lost the battle to be sole ruler of England, triumphing only in the sense that her son was crowned King Henry II at Stephen's death in 1154. Thus, Matilda was able to maintain her line on the throne even if she herself could not occupy it.

The pattern of Matilda's patronage has been studied by Marjorie Chibnall, who showed that it formed part of Matilda's intent to demonstrate her right to control the royal demesne. ${ }^{112}$ Gifts made by Stephen were neutralized in regions Matilda controlled, such as Bordesley Abbey (Fig. 14). It had been newly founded by one of Stephen's supporters with land granted by the king. When Matilda gained control of the region, she granted the land to one of her supporters and "refounded" the abbey, conferring on it higher status as a royal foundation. She also used the foundation of new monasteries, especially Cistercian and often in the name of loyal vassals, to consolidate her power within her sphere of influence. Like Urraca, Matilda demonstrated her place within her dynasty by providing for family foundations, both in England and in Normandy, where she lived after 1148. She often made gifts of jewels or used her resources to purchase land for donations, particularly to her preferred monastery at Bec-Hellouin near Rouen. ${ }^{113}$ She seems to have chosen Bec as the future site of her burial because the monks had cared for her during a near-fatal illness after the birth of her second son in 1134 and because her father's entrails were buried at Bec's priory church of Notre-Dame-

111 For Matilda's image on a coin, see George C. Boon, Coins of the Anarchy, 1135-54 (Cardiff, 1988), pp. 10-12, no. 9, and pp. 24-25, plate 6a. Urraca also minted coins with her name and image (see nn. 81 and 82, above). If Melisende issued coinage, none has survived, but neither can any coin be firmly identified with her husband during his reign in Jerusalem (see Folda, The Art of the Crusaders, p. 170). However, two coins tentatively associated with Fulk may just as well have pertained to Melisende. Neither has a monarch's name or image; rather, one shows the aedicule of the Church of the Holy Sepulchre, while the other shows a double-armed cross reminiscent of reliquaries of the true cross. Both have a Greek cross on the reverse. In n. 174, p. 530, Folda asks whether the cross coin could have been "issued in honor of the coronation of King Fulk and Queen Melisende on September 14,1131 , the festival of the exaltation of the Holy Cross." Following that, I would ask whether the aedicule coin could have been issued in honor of Melisende's second coronation with her son Baldwin III in 1143. Both took place at the Church of the Holy Sepulchre, which Folda argues Melisende was instrumental in restoring.

${ }^{112}$ For a historical analysis of Matilda's patronage of the church, see Marjorie Chibnall, "The Empress Matilda and Church Reform," Transactions of the Royal Historical Society, Sth ser., 38 (1988), 107-33. See also Chibnall, The Empress Matilda, pp. 127-37 and 177-94.

${ }^{113}$ Marjoric Chibnall focused on the queen's patronage of this abbey in "The Empress Matilda and Bec-Hellouin," Anglo-Norman Studies 10 (1988), 35-48, esp. p. 48 for Matilda's will. (I am grateful to Jean Truax for directing my attention to studies of Matilda's patronage.) 


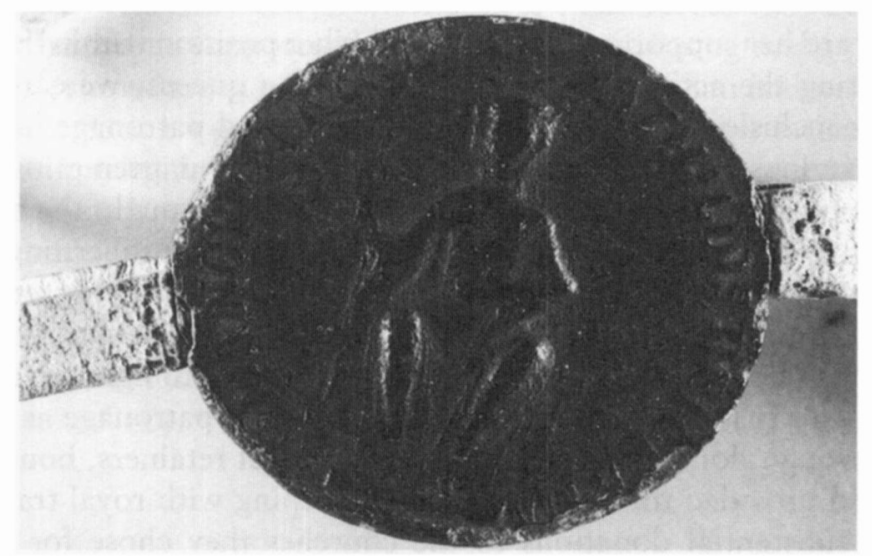

Fig. 14. Matilda's seal on a charter to Bordesley Abbey:

"Matildis Dei Gratia Romanorum Regina."

London, British Library, Add. Ch. 75724.

(Reproduced by permission.)

du-Pré, his body later being laid to rest at Reading Abbey in England. ${ }^{114}$ Matilda made substantial donations to the monks of Bec during her lifetime and willed them most of her wealth, including the richest jewels from among her regalia and relics brought from Germany. The list of her donations to Bec, including crowns, crosses, manuscripts, altars and altar goods, relics, and vestments, is truly impressive. ${ }^{115}$ Of the many treasures and vestments Matilda is recorded as having donated to various monasteries, just two are known to survive: a reddish gold silk dalmatic given to the abbey of Grandmont and preserved in the parish church of Ambazac, and a bejeweled golden reliquary cross associated with the monastery of Le Valasse, now in the Musée départementale at Rouen. ${ }^{16}$ Besides her generosity to churches, Matilda can also be seen to have taken an interest in improving the urban area surrounding Bec through her gift of money for the completion of a bridge across the Seine. The pattern of Matilda's patronage demonstrates a

${ }^{114}$ In 1141 Matilda granted five charters to Reading Abbey, where her father was interred. As Chibnall, The Empress Matilda, p. 130, points out, three of these donations superseded grants made by Stephen. Matilda had previously given her father the precious relic of the hand of St. James, which he gave to Reading. See Karl Leyser, "Frederick Barbarossa, Henry II and the Hand of St. James," English Historical Review 90 (1975), 481-506 (reprinted in his Medieval Germany and Its Neighbors, 900-1250, History Series 12 [London, 1982], pp. 215-40]).

${ }^{115}$ Unfortunately, the pieces that survived earlier dispersals were finally lost when Bec was destroyed by Napoleon.

${ }^{116}$ For the dalmatic, see Judy Martin and L. E. M. Walker, "At the Feet of St. Stephen Muret: Henry II and the Order of Grandmont Redivivus," Journal of Medieval History 16 (1990), 1-12, esp. p. 6 for an illustration. For the cross, see Elizabeth Hallam, ed., The Plantagenet Chronicles (London, 1986), p. 47 for an illustration. 
conscious use of donations similar to Urraca's, in order to solidify her political position, reward her supporters, and emphasize her position within the ruling line.

By comparing the actions of these three reigning queens, we can draw some preliminary conclusions about the roles of politics and patronage in the complicated maneuverings involved in a woman's achieving and attempting to hold the throne in the twelfth century. First, each of their fathers sought the agreement of his magnates for the unusual circumstance of a daughter inheriting. The kings chose sons-in-law who brought their daughters strong alliances in terms of lands, in the case of Matilda; a proven warrior, in the case of Melisende; or both, in the case of Urraca. These formidable women were prepared to fight for their right to reign, both literally in battle and figuratively by using patronage as one of their weapons. Through donations, they rewarded faithful retainers, bound wavering followers, and provided for religious sites. In keeping with royal tradition, these rulers made substantial donations to the churches they chose for their burial: Urraca to San Isidoro, Melisende to the Church of the Tomb of the Virgin in Jehosaphat, and Matilda to Bec-Hellouin in Normandy. Each site resonated as one already established for royal burial rather than a new foundation, underlining the need these queens had to demonstrate their place within a dynasty. ${ }^{117}$ Matilda spent nine years in England, actively, if in the end unsuccessfully, fighting for her place on the throne. Melisende held the throne alone for nine years, following twelve years of corule with her husband, before her son was able to oust her. Of the three reigning queens, only Urraca managed to retain the throne throughout her lifetime, but she died in her forties, while Matilda and Melisende lived into their sixties. One wonders if Urraca would have been able to continue in power as she aged and her son became increasingly impatient for his turn on the throne. Her early death in childbirth leaves that question open.

Urraca came from a line of military rulers, and I would suggest that her legitimacy as a leader was due only in part to the fact that Alfonso VI named her his heir. A great deal depended on her own sagacity during the following two decades. Urraca's ultimate success as monarch is obvious when one examines the political situation of her day. ${ }^{118}$ The powerful king of neighboring Aragon thought to take over all of León-Castile, first by marrying the crown princess and, when that proved ineffectual, by defeating her at war. That tactic also failed. That Urraca was able to maintain her hold on the throne against such an opponent speaks highly of her capacity as military leader and the success of her multiple strategies of rulership. As a commander, she clearly knew how to control her troops and maintain their loyalty. As a political strategist, she used patronage to form alli-

${ }^{117}$ Although Urraca's father had chosen to be buried at the royal monastery of Sahagún outside León, many other members of her dynasty were buried at San Isidoro. See Sánchez Ameijeiras, "Royal Tombs" (above, n. 29).

${ }^{118}$ When this article was in press, I came upon the following brief but incisive critique of the portrayal of Urraca in the Historia Compostellana, which should be added to the bibliography cited above on the queen: María Carmen Pallares and Ermelindo Portela, "La reina Urraca y el obispo Gelmírez: Nabot contra Jezabel," in Os reinos ibéricos na idade média: Livro de homenagem ao Professor Doutor Humberto Carlos Baquero Moreno, ed. Luís Adão da Fonseca, Luís Carlos Amaral, and Maria Fernanda Ferreira Santos, 2 (Porto, 2003), pp. 957-62. 
ances with both secular and religious lords, while she successfully held off other pretenders to the throne supported by mighty bishops. Recognizing the power of a visual symbol, she enlarged her family's palace chapel at San Isidoro and opened it to the public, creating a permanent reminder that she was her father's daughter, while claiming her legitimate place as descendant of the rulers of Toledo. The sophistication of such strategies, together with the fortuitous moment in the first half of the twelfth century when the role of queen had not yet calcified, allowed ambitious women like Queen Urraca to reign. After Urraca, more than three hundred years would pass before another Iberian queen, Isabel of Castile, would rule with such power and independence. 